\author{
Part of Journal of Research of the National Bureau of Standards, Volume 17, \\ November 1936
}

\title{
SOIL-CORROSION STUDIES, 1934. RATES OF LOSS OF WEIGHT AND PENETRATION OF NONFERROUS MATE- RIALS
}

\author{
By Kirk H. Logan
}

\begin{abstract}
The soil-corrosion investigation, which was started in 1922, had its origin in the need for information concerning the effects of soils on iron and steel. Specimens of protective coatings and of nonferrous metals were added from time to time, mostly at the request of manufacturers or others who were interested in the behavior of certain materials when exposed to certain soils. A systematic study of the corrosion of nonferrous materials underground was not begun until 1932, and in the latest tests the specimens represent only copper and copper alloys. The number of nonferrous specimens exposed to soils has grown to approximately 9,000 , of which about 2,500 have not been removed.

Differences in dimensions of the specimens buried prior to 1932, insufficient numbers of specimens of each material, and the introduction of too many factors that may affect corrosion have resulted in complications of the data to such an extent that in many cases positive decisions as to the rates of corrosion or the effects of possible influences on corrosion cannot be made. Nevertheless, although the dispersion of the data is large, certain tendencies are sufficiently well defined to be of practical importance. The results of the experiments should be of value also as indicators of the direction which more systematic investigations should take.

This report summarizes the effects of a large variety of soils on many nonferrous metals and alloys. Data on the corrosion of iron subjected to the same conditions are also given. In general, the nonferrous materials, with the possible exception of aluminum and its alloys, in certain soils corrode less than the ferrous materials under similar soil conditions, but none of the materials tested was free from corrosion in all soils. It appears, therefore, that in the choice of materials soil conditions should be given consideration. Unfortunately, few people have made systematic studies of soils from the standpoint of corrosion and not many can predict from the chemical or physical analysis of soils their effect on metals exposed to them.
\end{abstract}

The proper selection of materials for use underground requires special knowledge of soils, metals, electrochemistry, and economics.

\section{CONTENTS}

I. Introduction

II. Properties of soils at test sites_...

III. Corrosion of nonferrous metals and alloys

1. Corrosion of lead

2. Corrosion of copper and alloys of copper

3. Corrosion of aluminum and zinc

IV. Effect of interconnecting different metals

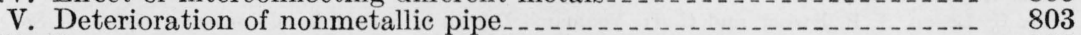

VI. Summary _........... 803 


\section{INTRODUCTION}

The original plans for the soil-corrosion investigation, which was started in 1922, dealt primarily with ferrous pipes, although the corrosion of cable sheath was given some consideration. When it appeared that ferrous materials corroded rather rapidly under some soil conditions, it seemed desirable to obtain data on nonferrous materials which might also be used underground.

Specimens of nonferrous materials were therefore added from time to time when ferrous specimens were removed. This paper concerns itself with these nonferrous materials. Like the reports on the ferrous materials, this is a progress report, and for a complete understanding of it the reader should refer to some of the earlier reports. The most important of these is Bureau Technologic Paper $368,{ }^{1}$ which described the soils in the original test, gives the analyses of some of the materials, and records the results of the examination of the first nonferrous specimens that were removed after an exposure of approximately 2 years. Research Paper $95^{2}$ contains data on the corrosion of lead cable sheath, and Research Papers 359 and $638^{3}$ contain corrosion data on a considerable variety of nonferrous materials.

\section{PROPERTIES OF SOILS AT TEST SITES}

Table 1 gives the names of the soils corresponding to the soil numbers, together with the locations of test site and the local organization cooperating in the test. Table 2 gives the properties of the soils. The test sites were selected as representative of typical soil conditions, and do not necessarily represent the prevailing soil conditions in the city near which the test was conducted. It should be remembered that within the boundaries of a city of moderate size there are usually several widely different soils.

TABLE 1.-Identification of soils

\begin{tabular}{|c|c|c|c|}
\hline Soil & Soil type & Location & Cooperating organization \\
\hline 1. & Allis silt loam. & Cleveland, Ohio. & East Ohio Gas Co. \\
\hline & Bell clay.................... & Dallas, Tex ....... & Dallas Gas Co. \\
\hline & Cecil clay loam & Atlanta, Ga....- & Dept. of Pub. Works. \\
\hline & Dublin clay adobe........ & Oakland, Calif .. & $\begin{array}{l}\text { Philadelphia Elec. Co. } \\
\text { East Bay Municipal Utility District. }\end{array}$ \\
\hline 6. & Everett gravelly sandy & Seattle, Wash... & Dept. of Pub. Works. \\
\hline & $\begin{array}{l}\text { loam. } \\
\text { Silt loam. }\end{array}$ & Cincinnat & Union Gas and Ele \\
\hline & Fargo clay loam. & Fargo, N. Dak & Union Light, Heat and Power Co. \\
\hline & Genesee silt loam & Sidney, Ohio & Tide Water Pipe Line Co., Ltd. \\
\hline & Glouchester sandy loam. & Middleboro, Mass _ & Town of Middleboro. \\
\hline & Hagerstown loam.. & Baltimore, $\mathrm{Md}$. & Dept. of Pub. Works. \\
\hline & $\begin{array}{l}\text { Hanford fine sandy } \\
\text { loam }\end{array}$ & Los Angeles, Calif & Southern Calif. Gas Co. \\
\hline 13 & Hanford very fine sandy & Bakersfield, Calif. & San Joaquin Light and Power Corp. \\
\hline $14-$ & $\begin{array}{l}\text { Hemstead silt loam...... } \\
\text { Houston black clay..... }\end{array}$ & $\begin{array}{l}\text { St. Paul, Minn } \\
\text { San Antonio, Tex........ }\end{array}$ & $\begin{array}{l}\text { Northern States Power Co. } \\
\text { San Antonio Public Service Co. }\end{array}$ \\
\hline
\end{tabular}

1 K. H. Logan, S. P. Ewing, and C. D. Yeomans, Bureau of Standards soil-corrosion studies: I. Soils, materials, and results of early observations. Tech. Pap. BS 22, 447 (1928) T368, 50c.

$\approx \mathrm{K}$. H. Logan, Soil-corrosion studies 1927-28. BSJ Research 3, 275 (1928) RP95, 10c.

$3 \mathrm{~K}$. H. Logan, Soil-corrosion studies; Nonferrous metals and alloys, metallic coatings, and specially prepared ferrous pipes removed in 193U, BS J Research 7, 585, (1931) RP359, 10c.

K. H. Logan and R. H. Taylor, Soil-corrosion studies 1932. Rates of loss of weight and pitting of ferrous and nonferrous specimens removed in 1932 and metallic protective coatings, BS J Research 12, 12, (1934) RP638, 5c. 
TABLE 1.-Identification of soils-Continued

\begin{tabular}{|c|c|c|c|}
\hline Soil & Soil type & Location & Cooperating organization \\
\hline & Kalmia fine sandy loam. & Mobile, Ala_. & City of Mobile. \\
\hline & Keyport loam & Alexandria, Va & Alexandria Water Co. \\
\hline & Knox silt loam & Omaha, Neb...... & Omaha and Council Bluffis Electrolysis \\
\hline & Lindley silt loam & Des Moines, Iowa & Des Moines Gas Co. \\
\hline & Mahoning silt loam..... & Cleveland, Ohio & Dept. of Pub. Utilities. \\
\hline & Memphis silt loam. & Memphis, Tenn & Board of Water Commissioners. \\
\hline & Merced silt loam & Buttonwillow, Cali & San Joaquin Light and Power Corp. \\
\hline $24-$ & $\begin{array}{l}\text { Merrimac gravelly } \\
\text { sandy loam. }\end{array}$ & Norwood, Mass.... & Boston Consolidated Gas Co. \\
\hline $\begin{array}{l}25 \\
26\end{array}$ & $\begin{array}{l}\text { Miami clay loam } \\
\text { Miami silt loam }\end{array}$ & $\begin{array}{l}\text { Milwaukee, Wis... } \\
\text { Springfield, Ohio_. }\end{array}$ & $\begin{array}{l}\text { Dept. of Pub. Works. } \\
\text { City of Springfield. }\end{array}$ \\
\hline 27. & Miller clay & Bunkie, La & Standard Pipe Line Co. \\
\hline & Montezuma clay adobe & San Diego, & $\begin{array}{l}\text { San Diego Consolidated Gas and Elec- } \\
\text { tric Co. }\end{array}$ \\
\hline 29 & $\begin{array}{l}\text { Muck } \\
\text { Museatine silt loam }\end{array}$ & $\begin{array}{l}\text { New Orleans, La... } \\
\text { Davenport, Iowa... }\end{array}$ & $\begin{array}{l}\text { Sewerage and Water Board. } \\
\text { United Light and Power Engineering an }\end{array}$ \\
\hline & & & Construction Co. \\
\hline & Norfolk sand. & Jacksonville, Fi & City Commission of Jacksonville. \\
\hline 32. & Ontario loam. & Rochester, N. Y & Dept. of Pub. Works. \\
\hline & Peat_........... & Milwaukee, Wis. & Milwaukee Gas Light Co. \\
\hline & $\begin{array}{l}\text { Penn silt loam } . . .-. \\
\text { Ramona loam }\end{array}$ & Los Angeles, Calif. & $\begin{array}{l}\text { Philadelphia Elec. Co. } \\
\text { Los Angeles Gas and Elec. Co. }\end{array}$ \\
\hline & Ruston sandy loam & Meridian, Miss... & Peoples Water and Gas Co. \\
\hline & St. Johns fine sand & Jacksonville, Fl & Jacksonville Gas Co. \\
\hline & $\begin{array}{l}\text { Sassafras gravelly sandy } \\
\text { loam. }\end{array}$ & & Camden Water Dept \\
\hline $\begin{array}{ll}39 \\
40\end{array}$ & $\begin{array}{l}\text { Sassafras silt loam } \\
\text { Sharkey clay }\end{array}$ & $\begin{array}{l}\text { Wilmington, Del- } \\
\text { New Orleans, La- }\end{array}$ & $\begin{array}{l}\text { Delaware Power and Light Co. } \\
\text { New Orleans Pub. Serv. Co. }\end{array}$ \\
\hline & Summit silt loam... & Kansas City, Mo & Kansas City Gas Co. \\
\hline & Susquehanna clay . & Meridian, Miss & City of Meridian \\
\hline 43. & $\begin{array}{l}\text { Tidal marsh } \\
\text { Wabash silt loam.......... }\end{array}$ & $\begin{array}{l}\text { Elizabeth, N. J... } \\
\text { Omaha, Neb..... }\end{array}$ & $\begin{array}{l}\text { Standard Oil Development Co. } \\
\text { Omaha and Council Bluffis Electroly }\end{array}$ \\
\hline & Unidentified alkali soil_. & Casper, Wy & Stanolind Oil and Gas Co. \\
\hline & Uniden & Den & Public Service Co. of Colo. \\
\hline & Unidentified silt loam.-- & Salt Lake City, & Mountain Fuel Supply Co \\
\hline & $\begin{array}{l}\text { Acadia ciay - } \\
\text { Cecil clay loa }\end{array}$ & Spindletop, Te & $\begin{array}{l}\text { Sinclair Prairie Pipe Line Co. of Tex. } \\
\text { Dept of Pub. Works. }\end{array}$ \\
\hline & nt silt loam. & ati, Ohio. & Union Gas and Elec. Co. \\
\hline & Hagerstown loam... & Baltimore, Md... & Bureau of Water Supply. \\
\hline & Lake Charles & El Vista, $\mathrm{Te}$ & Gulf Pipe Line Co. \\
\hline & Merced clay adobe.. & Tranquillity & Standard Oil Co. of Calif. \\
\hline & Muck & New Orleans, La.-- & Sewerage and Water Board. \\
\hline & Peat do & $\begin{array}{l}\text { Kalamazoo, Mich.. } \\
\text { Plymouth, Ohio }\end{array}$ & Dept of Pub. Utilities. \\
\hline & & & \\
\hline & Susqi & New Urieans, & $\begin{array}{l}\text { New Orleans Pub. } \\
\text { City of Meridian. }\end{array}$ \\
\hline & Tidal & Charleston, S. C. & Commissioners of Pub. Works. \\
\hline & Unidentified alkali soil_. & Cholame Flats, Calif. & Shell Oil Co. \\
\hline & - & Wilmington, Calif & Shell oil C \\
\hline & Mohave sandy loam.... & Phoenix, Ari & City Water Dept. \\
\hline & Cinders & Milwau & Milwaukee Gas Light Co. \\
\hline
\end{tabular}


TABLE 2.-Pioperties of soils ${ }^{a}$ in the National Bureau of Standards soil-corrosion investigation

(mg-eq = milligram equivalent)

$A=$ Alkaline

$G=$ Good; $F=$ Fair; $P=$ Poor; $V P=$ Very poor.

\begin{tabular}{|c|c|c|c|c|c|c|c|c|c|c|c|c|c|c|c|}
\hline \multirow[b]{2}{*}{ Soil ${ }^{3}$} & \multirow[b]{2}{*}{ Soil type } & \multirow{2}{*}{$\begin{array}{l}\text { Mean } \\
\text { tem- } \\
\text { pera- } \\
\text { ture }\end{array}$} & \multirow{2}{*}{$\begin{array}{l}\text { Annual } \\
\text { precipi- } \\
\text { tation } c\end{array}$} & \multirow{2}{*}{$\begin{array}{l}\text { Inter- } \\
\text { nal } \\
\text { drain- } \\
\text { age of } \\
\text { test } \\
\text { site }\end{array}$} & \multirow{2}{*}{$\begin{array}{c}\text { Moisture } \\
\text { equiva- } \\
\text { lent }\end{array}$} & \multirow[b]{2}{*}{$\mathrm{pH}$} & \multirow{2}{*}{$\begin{array}{l}\text { Total } \\
\text { acidity } \\
\mathrm{mg}-\mathrm{eq} \\
\text { per } 100 \mathrm{~g} \\
\text { of soil }\end{array}$} & \multirow{2}{*}{$\begin{array}{l}\text { Resis- } \\
\text { tivity } \\
\text { at } 60^{\circ} \mathrm{F}\end{array}$} & \multicolumn{7}{|c|}{ Composition of water extract mg-eq per $100 \mathrm{~g}$ of soil } \\
\hline & & & & & & & & & $\begin{array}{c}\mathrm{Na}+\mathrm{K} \\
\text { as Na }\end{array}$ & $\mathrm{Ca}$ & $\mathrm{Mg}$ & $\mathrm{CO}_{3}$ & $\mathrm{HCO}_{3}$ & $\mathrm{Cl}$ & $\mathrm{SO}_{4}$ \\
\hline $\begin{array}{c}51 \\
52 \\
1 \\
2 \\
101\end{array}$ & $\begin{array}{l}\text { Acadia clay } \\
\text { Alkali knoll } \\
\text { Allis silt loam } \\
\text { Bell clay } \\
\text { Billings silt loam }\end{array}$ & $\begin{array}{l}{ }^{\circ} \mathrm{F} \\
69 . \\
69 . \\
49.2 \\
65.5 \\
52.0\end{array}$ & $\begin{array}{l}49 . \\
47 . \\
33.8 \\
36.2 \\
8.8\end{array}$ & $\begin{array}{l}P \\
P \\
P \\
P \\
F\end{array}$ & \begin{tabular}{c|}
$\%$ \\
47.1 \\
54.8 \\
28.6 \\
37.6 \\
30.0
\end{tabular} & $\begin{array}{l}6.2 \\
8.8 \\
7.0 \\
7.3 \\
7.3\end{array}$ & $\begin{array}{l}13.2 \\
A 11.4 \\
A^{3.5}\end{array}$ & $\begin{array}{r}\text { ohm-cm } \\
190 \\
234 \\
1,215 \\
684 \\
261\end{array}$ & $\begin{array}{r}\text { 10. } 27 \\
4.20 \\
.72 \\
.28 \\
5.21\end{array}$ & $\begin{array}{r}15.55 \\
.33 \\
.25 \\
1.09 \\
19.24\end{array}$ & $\begin{array}{r}5.03 \\
.18 \\
.43 \\
.13 \\
1.43\end{array}$ & $\begin{array}{r}0.00 \\
.52 \\
.00 \\
.00 \\
.00\end{array}$ & $\begin{array}{r}0.56 \\
1.36 \\
.09 \\
1.18 \\
.66\end{array}$ & $\begin{array}{r}5.75 \\
1.33 \\
.09 \\
.04 \\
1.56\end{array}$ & $\begin{array}{r}22.00 \\
1.26 \\
.83 \\
.18 \\
22.48\end{array}$ \\
\hline $\begin{array}{r}102 \\
103 \\
104 \\
3 \\
53\end{array}$ & $\begin{array}{l}\text { Cecil clay } \\
\text { Cecil clay loam }\end{array}$ & $\begin{array}{l}52.0 \\
52.0 \\
60.2 \\
61.2 \\
61.2\end{array}$ & $\begin{array}{r}8.8 \\
8.8 \\
46.1 \\
48.3 \\
48.3\end{array}$ & $\begin{array}{l}F \\
F \\
G \\
G \\
G\end{array}$ & $\begin{array}{l}20.4 \\
30.6 \\
34.1 \\
29.1 \\
33.7\end{array}$ & $\begin{array}{l}7.3 \\
7.3 \\
4.6 \\
5.2 \\
4.6\end{array}$ & \begin{tabular}{l}
\multicolumn{1}{c}{$A$} \\
$A$ \\
11.0 \\
11.5 \\
9.6
\end{tabular} & $\begin{array}{r}103 \\
81 \\
8,500 \\
30,000 \\
17,794\end{array}$ & $\begin{array}{l}22.63 \\
22.01 \\
2\end{array}$ & $\begin{array}{l}16.56 \\
13.32 \\
\end{array}$ & \begin{tabular}{r}
3.85 \\
2.00 \\
\hdashline-10 \\
\end{tabular} & $\begin{array}{l}.00 \\
.00 \\
0\end{array}$ & $\begin{array}{l}.56 \\
.18 \\
-18 \\
-.-\end{array}$ & $\begin{array}{r}4.67 \\
11.09 \\
-0\end{array}$ & \begin{tabular}{r}
36.82 \\
25.70 \\
\hdashline \\
\hdashline-2 \\
$-י$
\end{tabular} \\
\hline $\begin{array}{r}105 \\
103 \\
107 \\
103 \\
4\end{array}$ & $\begin{array}{l}\text { Cecil fine sandy loam } \\
\text { Cecil gravelly loam } \\
\text { Chester loam }\end{array}$ & $\begin{array}{l}64.2 \\
60 . \\
60.1 \\
61.2 \\
54 .\end{array}$ & $\begin{array}{l}44.5 \\
46 . \\
46.3 \\
48.3 \\
40 .\end{array}$ & $\begin{array}{l}G \\
G \\
G \\
G \\
G \\
F\end{array}$ & \begin{tabular}{l|}
34.2 \\
38.8 \\
29.6 \\
34.3 \\
22.2
\end{tabular} & $\begin{array}{l}4.8 \\
4.8 \\
4.8 \\
4.9 \\
5.6\end{array}$ & $\begin{array}{r}12.9 \\
12.8 \\
11.8 \\
11.2 \\
7.6\end{array}$ & $\begin{array}{r}28,000 \\
25.000 \\
54,400 \\
44,400 \\
6,670\end{array}$ & - & - & - & - & . & - & 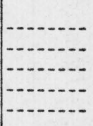 \\
\hline $\begin{array}{r}67 \\
5 \\
6 \\
5 / 4 \\
8\end{array}$ & $\begin{array}{l}\text { Cinders } \\
\text { Dublin clay adobe- } \\
\text { Everett gravelly sandy loam } \\
\text { Fairmount silt loam } \\
\text { Fargo clay loam }\end{array}$ & $\begin{array}{l}46.1 \\
56.4 \\
51.0 \\
53.2 \\
39 .\end{array}$ & $\begin{array}{l}30.1 \\
23.4 \\
34.0 \\
38.6 \\
21 .\end{array}$ & $\begin{array}{l}V P \\
P \\
G \\
P \\
P\end{array}$ & \begin{tabular}{l|}
11.1 \\
28.8 \\
12.2 \\
26.1 \\
37.0
\end{tabular} & $\begin{array}{l}\text { 8. } 0 \\
7.0 \\
5.9 \\
7.0 \\
7.6\end{array}$ & $\begin{array}{r}A_{6.5} \\
12.8 \\
A^{3.5}\end{array}$ & $\begin{array}{r}455 \\
1,346 \\
45,100 \\
886 \\
350\end{array}$ & \begin{tabular}{r}
.77 \\
.93 \\
\hdashline .59 \\
1.42
\end{tabular} & $\begin{array}{r}3.03 \\
.48 \\
10.10 \\
1.72\end{array}$ & $\begin{array}{r}.53 \\
.10 \\
2.59 \\
2.55\end{array}$ & $\begin{array}{l}.00 \\
.00 \\
.00 \\
.00\end{array}$ & $\begin{array}{l}.55 \\
.69 \\
.70 \\
.71\end{array}$ & $\begin{array}{l}.08 \\
.03 \\
.08 \\
.01\end{array}$ & $\begin{array}{r}2.89 \\
.25 \\
-9.05 \\
4.43\end{array}$ \\
\hline $\begin{array}{r}109 \\
110 \\
111 \\
9 \\
10\end{array}$ & \begin{tabular}{|l} 
Fresno fine sandy loam \\
Genesee silt loam \\
Gloucester sandy loam
\end{tabular} & $\begin{array}{l}63 . \\
63 . \\
63 . \\
50 . \\
50 .\end{array}$ & $\begin{array}{l}9 . \\
9 . \\
9 . \\
39.0 \\
41 .\end{array}$ & $\begin{array}{l}P \\
P \\
P \\
P \\
F\end{array}$ & $\begin{array}{l}18.6 \\
18.4 \\
22.1 \\
24.8 \\
13.0\end{array}$ & \begin{tabular}{r|}
8.4 \\
10.2 \\
7.3 \\
6.8 \\
6.6
\end{tabular} & $\begin{array}{l}A \\
A \\
A^{7.2} \\
\quad 3.6\end{array}$ & $\begin{array}{r}497 \\
531 \\
51 \\
2,820 \\
7,460\end{array}$ & $\begin{array}{r}2.62 \\
31.53 \\
41.55 \\
-.--\end{array}$ & $\begin{array}{r}.07 \\
.07 \\
16.21\end{array}$ & $\begin{array}{l}.10 \\
.12 \\
.44\end{array}$ & $\begin{array}{r}.31 \\
1.49 \\
.00\end{array}$ & $\begin{array}{r}.59 \\
1.07 \\
.58\end{array}$ & $\begin{array}{r}1.56 \\
.79 \\
34.58\end{array}$ & $\begin{array}{r}.48 \\
.25 \\
23.41 \\
\hdashline . . .\end{array}$ \\
\hline $\begin{array}{l}11 \\
55 \\
12 \\
13 \\
14\end{array}$ & $\begin{array}{l}\text { Hagerstown loam } \\
\text { Hanford fine sandy loam } \\
\text { Hanford very fine sandy loam. } \\
\text { Hempstead silt loam }\end{array}$ & $\begin{array}{l}55.4 \\
55.4 \\
62.4 \\
64.6 \\
44.2\end{array}$ & $\begin{array}{r}42.6 \\
42.6 \\
15.2 \\
5.6 \\
27.2\end{array}$ & $\begin{array}{l}G \\
G \\
F \\
F \\
F\end{array}$ & $\begin{array}{l}32.0 \\
32.0 \\
12.4 \\
21.7 \\
17.2\end{array}$ & $\begin{array}{l}5.3 \\
5.8 \\
7.1 \\
9.5 \\
6.2\end{array}$ & $\begin{array}{r}10.8 \\
10.9 \\
2.5 \\
A_{5.6}\end{array}$ & $\begin{array}{r}11,000 \\
5,213 \\
3,190 \\
290 \\
3,520\end{array}$ & $\begin{array}{l}.39 \\
6.23\end{array}$ & $\begin{array}{l}.50 \\
.09\end{array}$ & $\begin{array}{r}.16 \\
.13\end{array}$ & $\begin{array}{l}.00 \\
.00\end{array}$ & $\begin{array}{r}.40 \\
1.12\end{array}$ & $\begin{array}{l}.00 \\
1.64\end{array}$ & $\begin{array}{l}.14 \\
3.76\end{array}$ \\
\hline
\end{tabular}



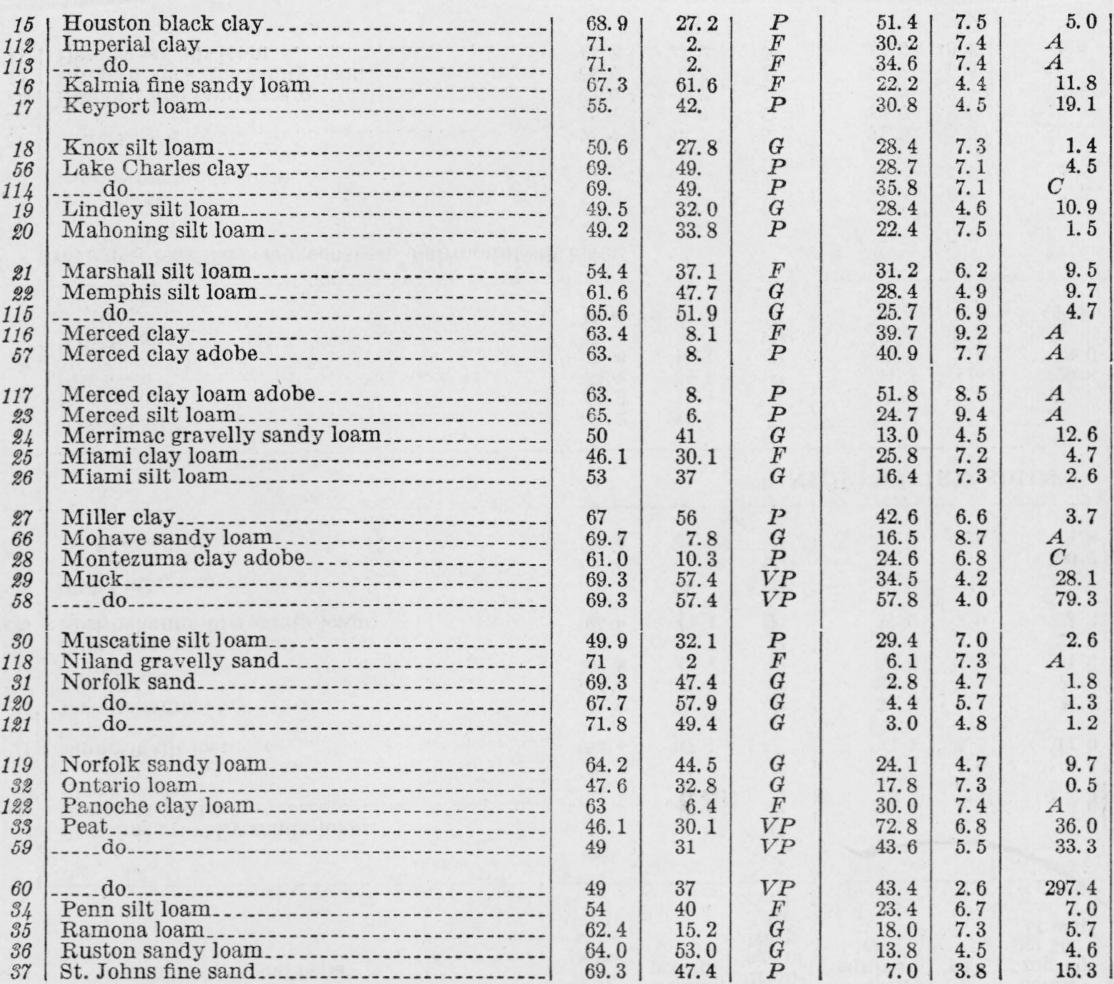

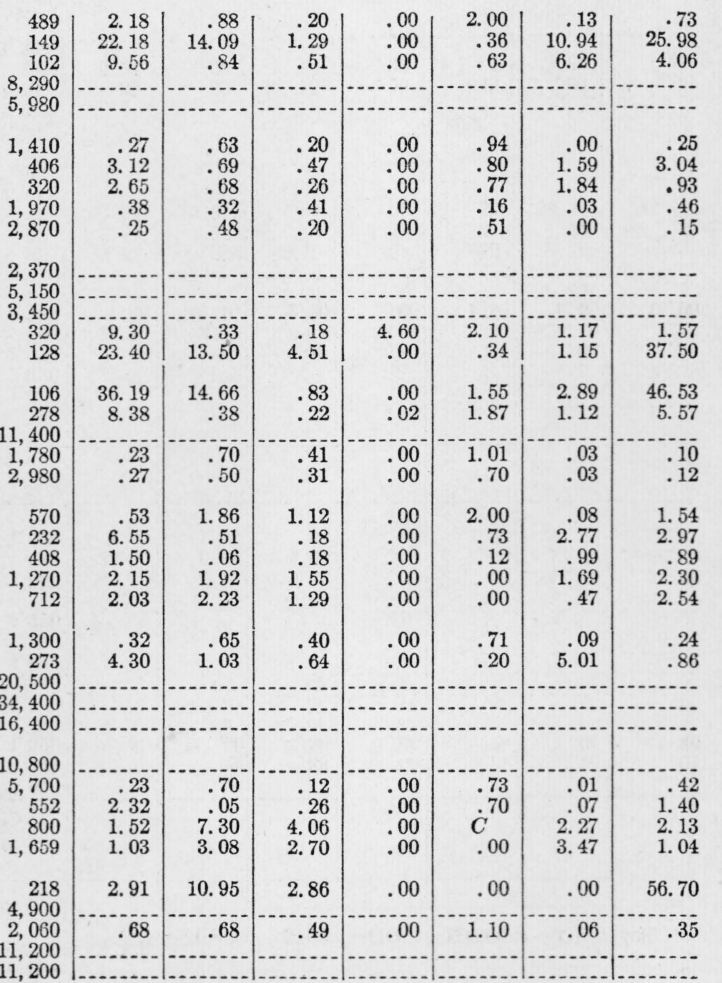

a Measurements and determinations by I. A. Denison and R. B. Hobbs.

- Data furnished by U. S. Weather Bureau. Values with no figures to the right of the decimal point are for some nearby city. 
TABLE 2.-Properties of soil in the National Bureau of Standards soil-corrosion investigation-Continued

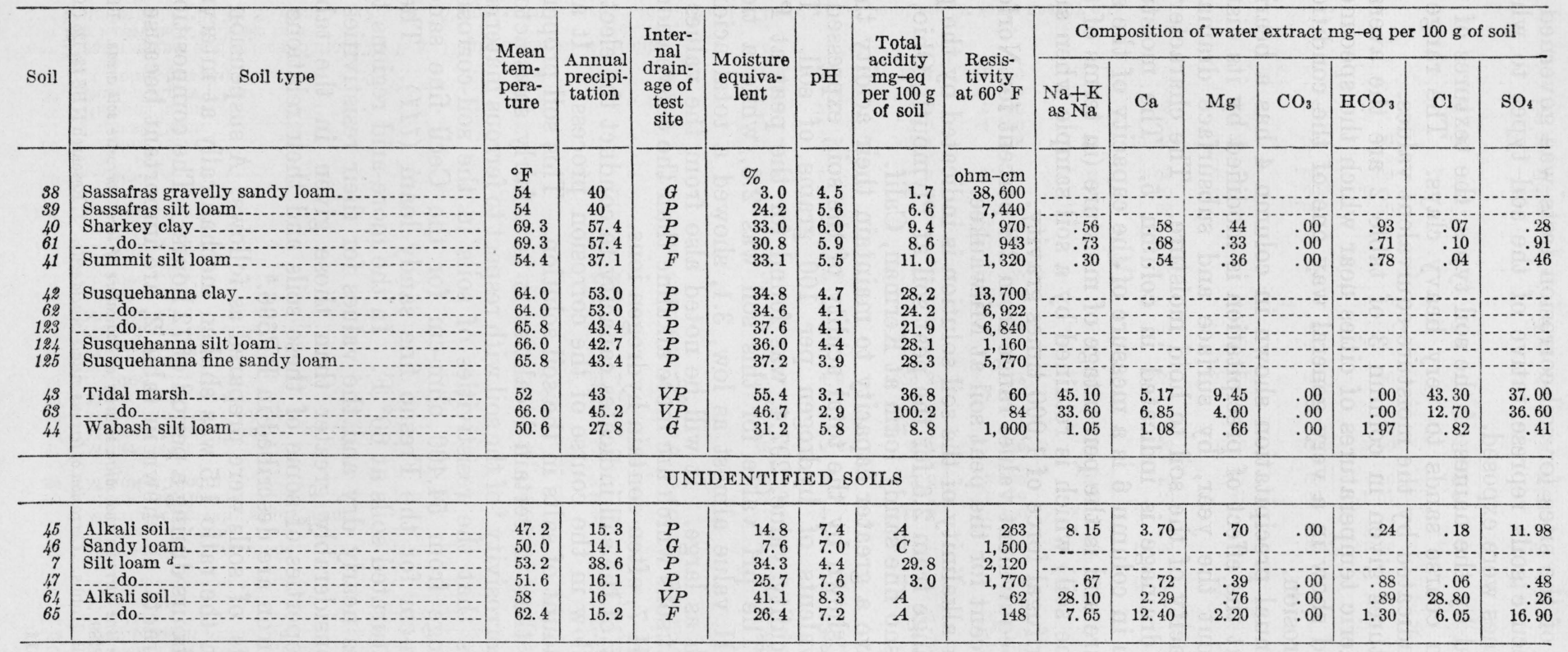

${ }^{d}$ Previously classified erroneously as Fairmount silt loam. 
The selection of the sites for soil-corrosion tests was governed by the desire to secure soils representative of the soil types to which extensive pipe lines were exposed.

As is indicated by the names of the soil types, the textures of the soils range from coarse sands to very heavy clays. The range in texture is also indicated by the moisture-equivalent values.

The temperatures given in column 3 of table 2 are the average annual atmospheric temperatures of cities near which the specimens were buried, and show in a very general way one of the conditions which affect corrosion.

The mean annual precipitation shown in column 4 has a bearing on corrosion, but the effect of precipitation is modified by its distribution throughout the year, by surface and subsurface drainage, and by the capacity of the soil to hold moisture. The character of the subsurface drainage is indicated in column 5 . The moisture equivalent given in column 6 is a measure of the capacity of the soil to retain moisture and is the percentage of moisture (in terms of the dry weight of the soil) which is retained by a soil sample when subjected to a centrifugal force of 1,000 times gravity.

The moisture-equivalent values range from 2.8 percent for Norfolk sand to 72.8 percent for the peat soil at Milwaukee.

The acidity or alkalinity of the soil solution is indicated by the $\mathrm{pH}$ values, which range from 2.6 for the peat soil at Plymouth, Ohio, to 10.2 for the Fresno fine sandy loam at Kerman, Calif.

Some soils have a greater capacity to maintain their acidity than others. This is shown by the total acidity of the soil, expressed in milligram equivalents of hydrogen per 100 grams of soil. The greatest total acidity value, 297.4, was found for the peat at Plymouth, Ohio. The $\mathrm{pH}$ value for this soil was 2.6 , while a tidal marsh with a $\mathrm{pH}$ value almost as low, 3.1, showed a total acidity about one-eighth as large. It will be noted also from the values of total acidity that soils which are more alkaline than the conventional neutral point, $\mathrm{pH} 7$, often contain hydrogen ions.

The resistivity of the soil indicates capacity to conduct the electric currents which flow in the course of the corrosion process. It also indicates the amount of salts in the soil solution. This soil property is so important that in certain localities it is a fairly satisfactory indicator of the corrosivity ${ }^{4}$ of the soil with respect to ferrous materials.

Table 2 shows that the resistivities of soils in the soil-corrosion investigation range from $54,400 \mathrm{ohm}-\mathrm{cm}$ for the Cecil fine sandy loam to $51 \mathrm{ohm}-\mathrm{cm}$ for the Fresno fine sandy loam (111). These values are for saturated soils at $60^{\circ} \mathrm{F}$. In the more-arid regions the soils are at times nearly dry and the values for their resistivities in the field are considerably greater than those given in the table. The physical properties of some of these soils and their relations to the corrosion of iron are described in RP696. ${ }^{5}$

Water extracts of soils were prepared as follows: A suspension of soil and water in the ratio 1:5 was shaken mechanically at intervals for a total of 24 hours during a period of 72 hours. The compositions of the water extracts, as shown in table 2, are important because of

\footnotetext{
1 E. R. Shepard. Pipe line currents and soilre sistivity as indicators of local corrosive soil areas. BS J. Research 6, 683 (1931) RP289.

5. A. Denison and R. B. Hobbs. Corrosion of ferrous metals in acid soils. J. Research NBS 13, 125 (1934) RP696, 5 c.
}

$99074-36-11$ 
the effect of the salts in solution on the resistivity of the soil and because of their influence of the character of the corrosion products, which may form protective deposits.

Since underground corrosion has been found to depend largely on soil conditions, an examination of table 2 will make clear that averages of corrosion data from different soils are of little practical value in the estimation of what is to be expected in any one locality.

Those interested in the classification of soils and their distribution will find part III of the Atlas of American Agriculture ${ }^{6}$ helpful. The paper does not discuss corrosion.

Table 3 shows the nonferrous materials reported in this paper, their symbols, dimensions, and actual or nominal compositions. In all cases except the lead the analyses were furnished by the manufacturer supplying the material. Such analyses are quite satisfactory for the study of underground corrosion since the precision with which rates of corrosion can be determined is not usually sufficient to show the effects of small changes in the composition of the materials tested.

\section{CORROSION OF NONFERROUS METALS AND ALLOYS}

\section{CORROSION OF LEAD}

Lead is used underground principally to provide a flexible connection between water mains and services, as water service pipe, and as a sheath for power and telephone cables. Power and telephone cables are usually drawn into ducts and therefore not exposed directly to soil action, although ducts may contain silt. Occasionally lead-covered cables are laid in direct contact with the soil, although this is not generally considered the best practice, partly because of the danger of damage when the soil is disturbed.

Four varieties of lead specimens appear in the soil-corrosion investigation, as shown in table 3. Table 4 shows the rates of corrosion for the cable sheath materials. For the rates of corrosion comparison of wrought iron and steel buried approximately 12 years in the same soils areincluded. Each rate for thelead is based on a single specimen. Most of the antimonial lead specimens were of approximately twice the area of those of commercial lead. The maximum rates of penetration of the former as recorded in the table represent the average of the two deepest pits on separate halves of the specimen. In the earlier reports the recorded maximum rate of penetration regardless of the dimensions of the specimen, is based upon the average of the deepest pit on each side of the specimen.

It is of interest to note that in certain soils which are very corrosive with respect to iron, such as Hanford very fine sandy loam, Merced silt loam, and other alkali soils, lead corrodes but slowly. Table 4 shows that in 32 out of 35 cases the antimonial lead specimens $A$ lost weight more rapidly than those of commercially pure lead, $H$, also the rate of penetration was greater in 20 instances. Similar indications of the greater corrodibility of the antimonial lead specimens were observed on previous examinations of these materials. It will be noted, however, that the variation in the rates of corrosion in different soils is much greater than the differences between the two materials.

\footnotetext{
6 C. F. Marbut. Soils of the United States. Part III of the Atlas of American Agriculture, July 1935, Government Printing Office, $\$ 5.00$.
} 
TABLE 3.-Form, dimensions, and chemical composition of materials

LEAD ALLOYS •

\begin{tabular}{|c|c|c|c|c|c|c|c|c|c|}
\hline \multirow{2}{*}{$\begin{array}{c}\text { Sym } \\
\text { bol }\end{array}$} & \multirow{2}{*}{ Material } & \multirow{2}{*}{ Form } & \multirow{2}{*}{ Dimensions ${ }^{\circ}$} & \multicolumn{6}{|c|}{ Chemical composition (in percent) } \\
\hline & & & & $\mathrm{Cu}$ & $\mathrm{Zn}$ & Sn & $\mathrm{Pb}$ & $\mathrm{Ni}$ & Other elements \\
\hline NN & Hearth refined & Cast.... & $\begin{array}{r}\text { Inches } \\
6 \times 2 \times .25\end{array}$ & 0.002 & & & 99.99 & & $0.004 \mathrm{Bi}$. \\
\hline $\begin{array}{l}N \\
H \\
A\end{array}$ & $\begin{array}{l}\text { Chemical lead- } \\
\text { Commercial lead } \\
\text { Antimonial lead. }\end{array}$ & Sheet... & $\begin{array}{l}6 \times 2 \times .25 \\
22 \times 3.5 \times 11 \ldots \\
22 \times 8.5 \times 12 \ldots \\
\end{array}$ & $\begin{array}{l}.57 \\
.013 \\
.062\end{array}$ & & & \begin{tabular}{|l}
99.93 \\
99.95 \\
99.12
\end{tabular} & \begin{tabular}{l}
$-\cdot \cdot$ \\
\hdashline$-\cdot$ \\
$\cdots$
\end{tabular} & $\begin{array}{l}0.009 \mathrm{Ag} . \\
0.037 \mathrm{Bi} \\
0.82 \mathrm{Sb} .\end{array}$ \\
\hline
\end{tabular}

COPPER ALLOYS

\begin{tabular}{|c|c|c|c|c|c|c|c|c|c|}
\hline $\begin{array}{l}E \\
C \\
M \\
A \\
P\end{array}$ & $\begin{array}{c}\text { Copper } \\
\text { do } \\
\text { do do } \\
\text { do do }\end{array}$ & 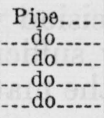 & $\begin{array}{l}17 \times 1.1 \times .108 \\
12 \times 1.7 \times .145 \ldots \\
12 \times .9 \times .06 \\
13 \times 1.7 \times .144 \\
12 \times .9 \times .06\end{array}$ & $\begin{array}{l}99.97 \\
99.9 \\
99.93 \\
99.94 \\
99.94\end{array}$ & 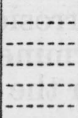 & - & - & 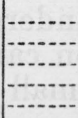 & $\begin{array}{l}0.018 \mathrm{P} \text {. } \\
0.015 \mathrm{P} \text {. }\end{array}$ \\
\hline $\begin{array}{c}M c \\
H \\
3 \\
2 \\
1\end{array}$ & 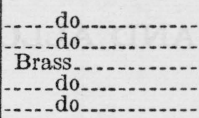 & 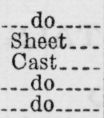 & \begin{tabular}{l}
$12 \times 1.5 \times .062$ \\
$6 \times 2 \times .05$ \\
Irregular........ \\
\hdashline$\ldots$ do \\
\end{tabular} & $\begin{array}{l}99+ \\
91.86 \\
87.06 \\
85.48\end{array}$ & $\begin{array}{l}7.72 \\
5.31 \\
6.20\end{array}$ & $\begin{array}{l}0.08 \\
5.86 \\
3.52\end{array}$ & $\begin{array}{l}0.34 \\
1.77 \\
4.80\end{array}$ & $\begin{array}{l}-- \\
-- \\
--\end{array}$ & \\
\hline $\begin{array}{l}F \\
H \\
\stackrel{4}{H} \\
\stackrel{B}{B 1}\end{array}$ & 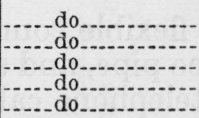 & $\begin{array}{l}\text { Pipe.... } \\
\text { Cast_.... } \\
\text { Pipe_... } \\
\text { Sheet... }\end{array}$ & $\begin{array}{l}12 \times 1.7 \times .143 \\
17 \times 1.1 \times .108 \ldots \\
\text { Irregular } \\
12 \times 1.7 \times .143 . \\
6 \times 2 \times .05 \\
.\end{array}$ & $\begin{array}{l}85.18 \\
84.99 \\
74.94 \\
71.28 \\
70\end{array}$ & $\begin{array}{l}14.80 \\
14.97 \\
20.12 \\
27.39 \\
30\end{array}$ & $\begin{array}{l}1.43 \\
1.30\end{array}$ & $\begin{array}{r}.01 \\
2.57 \\
.01\end{array}$ & -1 & $\begin{array}{l}0.01 \mathrm{Fe} . \\
0.03 \mathrm{Fe} . \\
0.94 \mathrm{Fe} . \\
0.02 \mathrm{Fe} .\end{array}$ \\
\hline $\begin{array}{l}K \\
J \\
B \\
B 2 \\
L\end{array}$ & 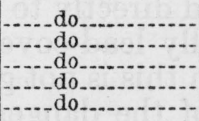 & $\begin{array}{l}\text { Pipe..... } \\
\text { do do..... } \\
\text { Nipple.. } \\
\text { Pipe.... }\end{array}$ & $\begin{array}{l}12 \times 1.7 \times .08 \\
13 \times 1.7 \times .145 \\
12 \times .8 \times .103 \\
2 \times .8 \times .106 \\
12 \times 1.7 \times .08\end{array}$ & $\begin{array}{l}67.08 \\
66.50 \\
60 \\
60 \\
60.06\end{array}$ & $\begin{array}{l}31.07 \\
33.06 \\
40 \\
40 \\
39.58\end{array}$ & 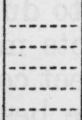 & .36 & - & $\begin{array}{l}\text { Trace of } \mathrm{Fe} \text {. } \\
0.02 \mathrm{Fe} \text {. } \\
\text { Trace of } \mathrm{Fe} \text {. }\end{array}$ \\
\hline$\underset{A}{M e}$ & 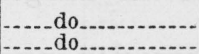 & Ell..... & $\begin{array}{l}2 \times .7 \times .16 \\
12 \times .4\end{array}$ & $\begin{array}{l}59.00 \\
47.00\end{array}$ & $\begin{array}{l}38.50 \\
40.50\end{array}$ & & $\begin{array}{l}2.50 \\
2.50\end{array}$ & 10 & \\
\hline $\begin{array}{l}E \\
L\end{array}$ & $\begin{array}{l}\text { Bronze... } \\
\text { Bronze. }\end{array}$ & $\begin{array}{l}\text { Pipe..... } \\
\text { Plate....- }\end{array}$ & $\begin{array}{l}12 \times 1.7 \times .141 \\
6 \times 2 \times .25\end{array}$ & $\begin{array}{l}97.15 \\
90\end{array}$ & & $\begin{array}{l}1.80 \\
10\end{array}$ & & & $\left\{\begin{array}{l}0.01 \mathrm{Fe} \\
1.04 \mathrm{Si} .\end{array}\right.$ \\
\hline $\begin{array}{l}N d \\
D\end{array}$ & $\mathrm{Cu}-\mathrm{Si}$ alloy........... & Pipe. & $12 \times 1.7 \times 143$ & 95.46 & & .14 & & 0.01 & $\left\{\begin{array}{l}0.11 \mathrm{Fe} . \\
.18 \mathrm{Mn} . \\
1.49 \mathrm{Si} . \\
.21 \mathrm{Fe} . \\
1.06 \mathrm{Mn}\end{array}\right.$ \\
\hline $\begin{array}{l}G \\
N \\
Z 1 \\
Z Z \\
\mathrm{P}\end{array}$ & $\begin{array}{l}\mathrm{Cu}-\mathrm{Ni} \text { alloy } \\
\mathrm{Cu}-\mathrm{Al} \text { alloy } \\
\mathrm{Zinc}\end{array}$ & $\begin{array}{l}\text { Rod...... } \\
\text { Sheet... } \\
\text { Plate.... } \\
\text { Sheet... }\end{array}$ & $\begin{array}{l}12 \times 1.7 \times .145 \\
12 \times .4 \\
6 \times 2 \times .06 \\
6 \times 2 \times .25 \\
6 \times 2 \times .06\end{array}$ & \begin{tabular}{c}
74.45 \\
87.00 \\
\hdashline$(\bullet)$
\end{tabular} & $\begin{array}{c}4.99 \\
99.5 \\
99.5 \\
(\bullet)\end{array}$ & 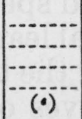 & $(\bullet)$ & \begin{tabular}{c}
20.04 \\
\hdashline$(c)$
\end{tabular} & $\begin{array}{l}0.52 \mathrm{Mn} \text {. } \\
3.5 \mathrm{Fe}, 9.5 \mathrm{Al} \text {. }\end{array}$ \\
\hline
\end{tabular}

ALUMINUM ALLOYS

\begin{tabular}{|c|c|c|c|c|c|c|c|c|c|}
\hline & & & & $\mathrm{Cu}$ & Fe & Si & Mn & $\mathrm{Al}$ & \\
\hline $\begin{array}{l}C 1 \\
C 2\end{array}$ & $\begin{array}{l}\text { Aluminum } \\
\text { Al-Mn }\end{array}$ & Sheet... & $\begin{array}{l}6 \times 2 \times .06 \\
6 \times 2 \times .06\end{array}$ & $\begin{array}{l}0.09 \\
.16\end{array}$ & $\begin{array}{l}0.33 \\
.51\end{array}$ & $\begin{array}{l}0.3 \\
.44\end{array}$ & $\begin{array}{l}0.03 \\
1.12\end{array}$ & $\begin{array}{l}99.25 \\
97.75\end{array}$ & $0.02 \mathrm{Zn}$. \\
\hline$C 3$ & Duralumin & $\ldots$ do & $6 \times 2 \times .06 \ldots$ & 4. 10 & & & .62 & 94.23 & $0.52 \mathrm{Mg}$. \\
\hline
\end{tabular}

a Analysis by J. A. Scherrer, National Bureau of Standards.

$\checkmark$ Dimensions of plates and sheets given as (length) $\times($ width) $\times$ (thickness); dimensions of pipes as (length) $\times$ (outside diameter) $\times$ (wall thickness); dimensions of rods as (length) $\times$ (diameter).

These specimens have streamlined caps and couplings soldered in place.

d Some of these specimens have brazed joints.

- Standard composition. 
TABLE 4.-Rates of loss of weight and maximum penetration lead cable sheath exposed 10 to 12 years

\begin{tabular}{|c|c|c|c|c|c|c|}
\hline \multirow[b]{2}{*}{ il a } & \multicolumn{2}{|c|}{$\begin{array}{l}\text { Cable sheath rates of } \\
\text { loss }(\mathrm{oz} / \mathrm{ft} 2 / \mathrm{yr})\end{array}$} & \multicolumn{2}{|c|}{ Rates $\begin{array}{l}\text { of penetration } \\
\text { (mils/yr) }\end{array}$} & \multicolumn{2}{|c|}{ Ferrous pipe } \\
\hline & $A^{b}$ & $\mathrm{H}^{\circ}$ & $A^{b}$ & $\mathrm{H}^{\circ}$ & $\begin{array}{c}\text { Rates of } \\
\text { loss (oz/- } \\
\left.\mathrm{ft}^{2} / \mathrm{yr}\right)\end{array}$ & $\begin{array}{c}\text { Rates of } \\
\text { penetration } \\
\text { (mils/yr) }\end{array}$ \\
\hline de. & $\begin{array}{r}0.345 \\
.095 \\
.062 \\
.149 \\
.185\end{array}$ & $\begin{array}{r}0.173 \\
.067 \\
.059 \\
.177 \\
.135\end{array}$ & $\begin{array}{r}8.1 \\
2.0 \\
.8 \\
5.3 \\
11.8\end{array}$ & $\begin{array}{l}9.4 \\
2.1 \\
1.8 \\
4.3 \\
4.0\end{array}$ & $\begin{array}{r}0.79 \\
.51 \\
.37 \\
.57 \\
.57\end{array}$ & $\begin{array}{l}7.5 \\
4.7 \\
5.8 \\
8.2 \\
3.5\end{array}$ \\
\hline$b^{d}$ & $\begin{array}{l}.035 \\
.074 \\
.040 \\
.181 \\
.051\end{array}$ & $\begin{array}{l}.025 \\
.088 \\
.034 \\
.049 \\
.036\end{array}$ & $\begin{array}{l}1.0 \\
1.7 \\
1.9 \\
5.2 \\
1.4\end{array}$ & $\begin{array}{l}1.1 \\
1.3 \\
1.3 \\
2.0 \\
2.5\end{array}$ & $\begin{array}{l}.10 \\
.40 \\
.17 \\
.39 \\
.68\end{array}$ & $\begin{array}{l}1.7 \\
3.8 \\
6.2 \\
8.2 \\
5.1\end{array}$ \\
\hline $\begin{array}{l}17 \\
18 \\
19 \\
20 \\
22\end{array}$ & $\begin{array}{l}.037 \\
.042 \\
.113 \\
.304 \\
.155\end{array}$ & $\begin{array}{l}.028 \\
.016 \\
.040 \\
.268 \\
.085\end{array}$ & $\begin{array}{l}2.9 \\
1.6 \\
2.8 \\
6.6 \\
2.5\end{array}$ & $\begin{array}{l}1.7 \\
1.3 \\
1.3 \\
4.4 \\
1.6\end{array}$ & $\begin{array}{l}.80 \\
.24 \\
.29 \\
.52 \\
.64\end{array}$ & $\begin{array}{l}3.5 \\
3.8 \\
5.5 \\
5.2 \\
5.6\end{array}$ \\
\hline $\begin{array}{l}24 \\
25 \\
26 \\
26 \mathrm{~d} \\
28 \\
28\end{array}$ & $\begin{array}{l}.021 \\
.045 \\
.041 \\
.095 \\
.221\end{array}$ & $\begin{array}{l}.015 \\
.028 \\
.018 \\
.067 \\
.069\end{array}$ & $\begin{array}{l}1.3 \\
3.0 \\
1.8 \\
3.3 \\
4.0\end{array}$ & $\begin{array}{l}1.6 \\
2.4 \\
2.5 \\
2.7 \\
1.0\end{array}$ & $\begin{array}{r}.12 \\
.28 \\
.32 \\
.66 \\
1.70\end{array}$ & $\begin{array}{r}2.2 \\
3.9 \\
3.5 \\
4.9 \\
16.4\end{array}$ \\
\hline 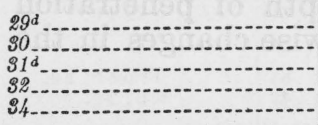 & $\begin{array}{r}.353 \\
.201 \\
.026 \\
.050 \\
.260\end{array}$ & $\begin{array}{l}.343 \\
.126 \\
.022 \\
.028 \\
.067\end{array}$ & $\begin{array}{l}1.4 \\
5.7 \\
1.3 \\
1.0 \\
7.6\end{array}$ & $\begin{array}{l}1.1 \\
4.4 \\
.7 \\
1.5 \\
9.2\end{array}$ & $\begin{array}{l}1.50 \\
.47 \\
.24 \\
.30 \\
.38\end{array}$ & $\begin{array}{r}11.4 \\
4.8 \\
2.8 \\
5.2 \\
3.7\end{array}$ \\
\hline $\begin{array}{l}85^{d} \\
86^{d} \\
88 \\
89 \\
41\end{array}$ & $\begin{array}{l}.019 \\
.046 \\
.032 \\
.048 \\
.049\end{array}$ & $\begin{array}{l}.017 \\
.032 \\
.025 \\
.099 \\
.039\end{array}$ & $\begin{array}{l}2.1 \\
1.2 \\
1.0 \\
3.5 \\
1.6\end{array}$ & $\begin{array}{l}3.4 \\
1.4 \\
2.1 \\
3.0 \\
1.6\end{array}$ & $\begin{array}{l}.16 \\
.23 \\
.20 \\
.47 \\
.51\end{array}$ & $\begin{array}{l}1.9 \\
4.0 \\
2.4 \\
5.8 \\
6.9\end{array}$ \\
\hline $\begin{array}{l}49 \\
445 \\
45 \\
46 \\
47-0\end{array}$ & $\begin{array}{l}.043 \\
.070 \\
.038 \\
.081 \\
.130\end{array}$ & $\begin{array}{l}.019 \\
.038 \\
.021 \\
.015 \\
.122\end{array}$ & $\begin{array}{l}1.9 \\
1.7 \\
1.2 \\
2.8 \\
4.8\end{array}$ & $\begin{array}{l}1.2 \\
1.1 \\
2.0 \\
1.2 \\
9.1\end{array}$ & $\begin{array}{r}1.31 \\
.30 \\
.85 \\
.38 \\
.25\end{array}$ & $\begin{array}{l}7.8 \\
5.8 \\
7.7 \\
6.2 \\
2.2\end{array}$ \\
\hline
\end{tabular}

- See table 1 for names of soils.

b Antimonial lead.

- Commercial lead.

d The antimonial lead specimens in these soils were 4.25 inches wide and the rate of penetration is based on the depth of the one deepest pit.

In most of the soils the rate of corrosion of the lead specimens is much lower than that of the corresponding ferrous specimens. In Allis silt loam (1), Dublin clay adobe (5), Mahoning silt loam (20), Muscatine silt loam (30), Penn silt loam (34), Ramona loam (35) and in the unidentified silt loam at Salt Lake City $(47)$, the averages of the rates of penetration for the lead specimens are greater than for the corresponding ferrous specimens. These soils are not severely corrosive with respect to ferrous materials. Their chief common characteristic is their low content of sulfates, as will be seen in table 2 . It will also be seen from comparing tables 2 and 4 that the lead did not corrode severely in soils high in sulfates.

The data in table 4 should be used with considerable caution for several reasons. Two specimens of the same material in the same soil may not corrode at the same rate. This is illustrated in table 5 where it will be noted that in some instances one specimen corroded 
50 percent more rapidly than another specimen of the same material under nominally the same soil condition. This illustrates a soilcorrosion phenomenon which is common to all outdoor soil-corrosion

TABLE 5.-Dispersion of rates of corrosion of lead SOIL 22.-12-YEARS' EXPOSURE

\begin{tabular}{|l|r|r|}
\hline Material & $\begin{array}{r}\text { Loss of } \\
\text { weight }\end{array}$ & $\begin{array}{c}\text { Maximum } \\
\text { penetration }\end{array}$ \\
\hline & oz/ft $2 / \mathrm{yr}$ & $\mathrm{mils} / \mathrm{yr}$ \\
A197 & 0.168 & 3.2 \\
H198. & .129 & 2.3 \\
$H 197$ & .087 & 1.4 \\
& .082 & 2.0 \\
\hline
\end{tabular}

SOIL 29.-10-YEARS' EXPOSURE

\begin{tabular}{|r|r|r|}
\hline$A 52$ & & \\
$A 53$ & 0.446 & 1.4 \\
$H 52_{2}$ & .259 & 1.4 \\
$H 53$ & .443 & 1.3 \\
& .242 & 1.0 \\
\hline
\end{tabular}

tests in which the soils are not in some way modified to secure unusually uniform soil conditions. The data as here presented do not reveal the effect of shape or area on the depth of penetration as has been shown in Research Paper 883. ${ }^{7}$ Likewise changes in the rate of corrosion are not indicated.

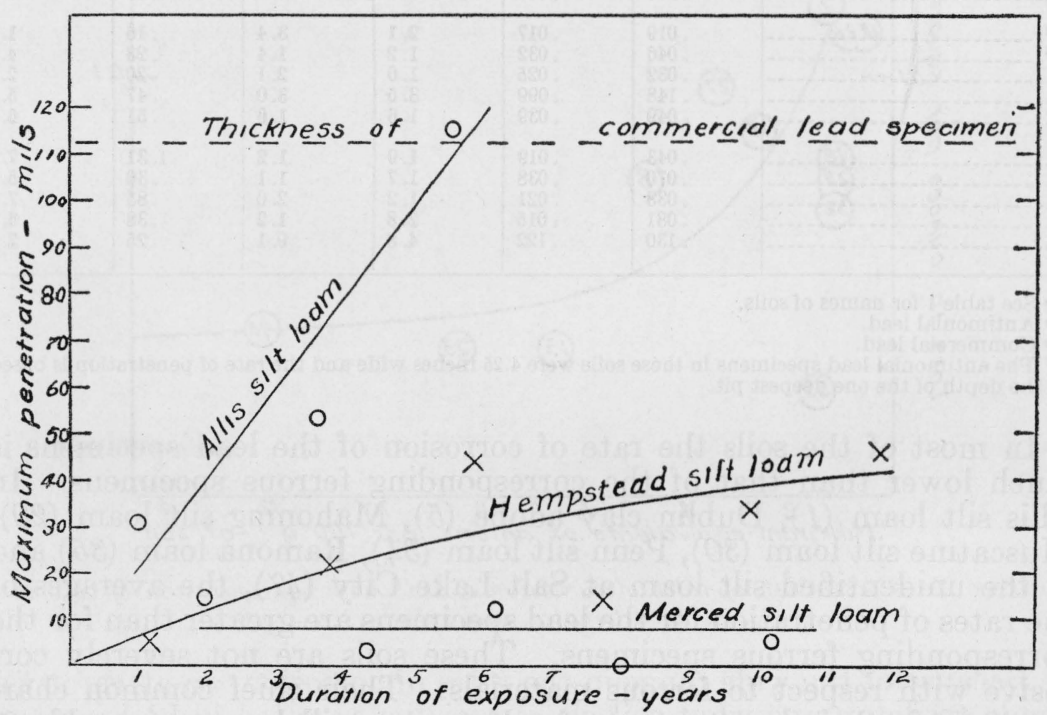

FIGURE 1.-Pit depth-time graphs for lead sheaths in three soils.

The influence of duration of exposure on the depth of the pits on lead is illustrated in figure 1 . The pit depths are the averages of the

\footnotetext{
${ }^{7}$ K. H. Logan. Soil-corrosion studies 1934. Rates of loss of weight and penetration of ferrous specimens. J. Research NBS 16, 431 (1936) RP883.
} 
two deepest pits, one on each side on each of two specimens, one of commercial lead and the other of antimonial lead. It is noted that in Merced silt loam, a soil high in sulfates, the pits increased in depth very little, if at all, as the period of exposure was prolonged. Apparently, a very effective coating, probably of lead sulfate, was formed. In Hempstead silt loam the penetration continued but at a decreasing rate; while in Allis silt loam the penetration was approximately proportional to the duration of exposure up to 6 years, at which time the specimens were punctured.

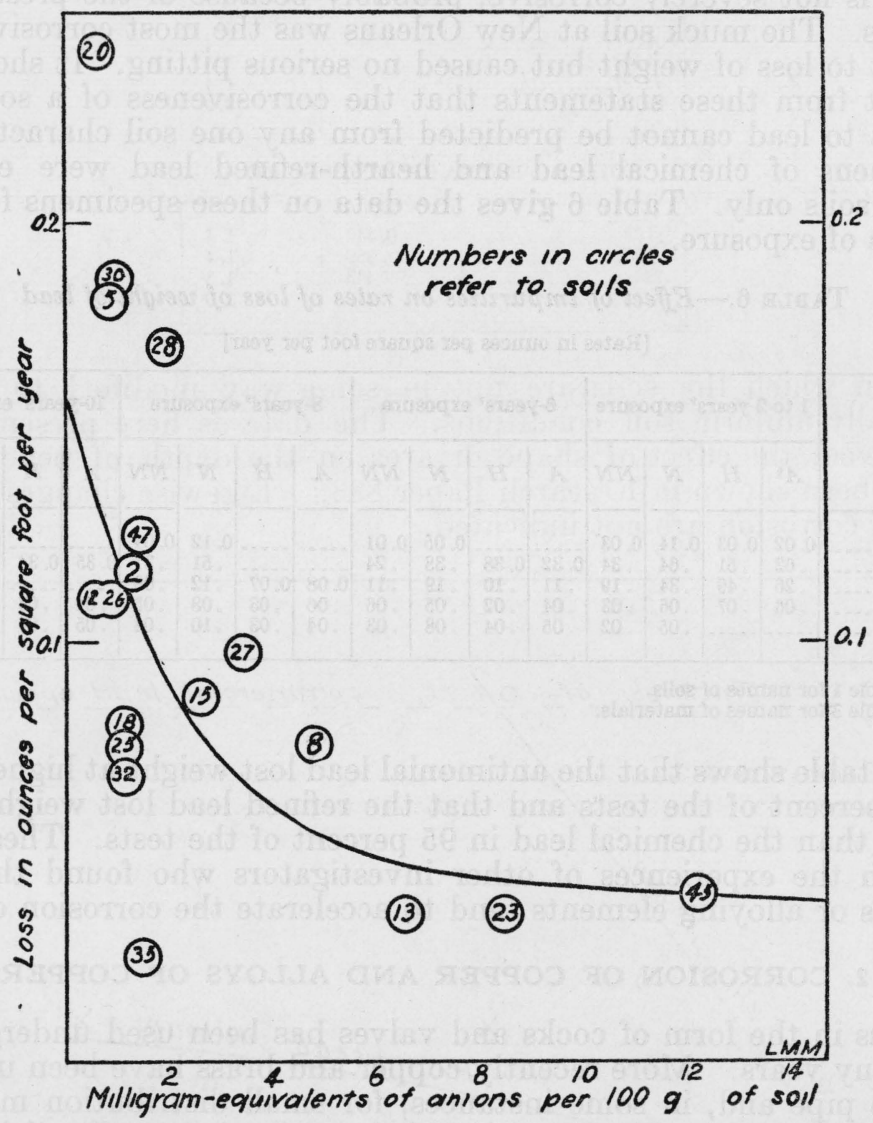

FIGURE 2.-Correlation of rates of corrosion of lead with concentration of chlorides, bicarbonates, and sulfates.

Because of the wide range in the rates of corrosion, an attempt was made to determine what soil characteristics resulted in high rates of corrosion of lead. This has not been altogether successful because of insufficient data and the large number of different factors involved in each soil condition. Figure 2 shows the relation between the concentration of chlorides, bicarbonates, and sulfates in some of the soils to the averages of the rates of loss of weight for periods of exposure varying between 2 and 12 years. The addition of the available data for other soils would not materially affect the shape of the curve, 
although it would be extended. Sulfates predominated in these soils. Although the curve shows in a general way that the salts tended to reduce the corrosion of lead, it should not be used for determining the loss of lead because the rates used are average rates, whereas, as was shown in figure 1, the change in the rate of corrosion with time is different for different soils.

In general, soils containing large quantities of organic material and soils which are poorly drained, appear to be corrosive to lead, but exceptions to this statement may be found. For example, the tidal marsh is not severely corrosive, probably because of the presence of sulfates. The muck soil at New Orleans was the most corrosive with respect to loss of weight but caused no serious pitting. It should be evident from these statements that the corrosiveness of a soil with respect to lead cannot be predicted from any one soil characteristic. Specimens of chemical lead and hearth-refined lead were exposed to five soils only. Table 6 gives the data on these specimens for four periods of exposure.

TABLE 6.-Effect of impurities on rates of loss of weight of lead

[Rates in ounces per square foot per year]

\begin{tabular}{|c|c|c|c|c|c|c|c|c|c|c|c|c|c|c|c|c|}
\hline \multirow{2}{*}{ Soil 1} & \multicolumn{4}{|c|}{1 to 2 years' exposure } & \multicolumn{4}{|c|}{ 6-years' exposure } & \multicolumn{4}{|c|}{ 8-years' exposure } & \multicolumn{4}{|c|}{ 10-years' exposure } \\
\hline & $A^{3}$ & $H$ & $N$ & $N N$ & $A$ & $H$ & $N$ & $N N$ & $A$ & $H$ & $N$ & $N N$ & $A$ & $H$ & $N$ & $N N$ \\
\hline $\begin{array}{l}29 . \\
42 . \\
43 . \\
45 .\end{array}$ & $\begin{array}{c}0.02 \\
.62 \\
.26 \\
.06 \\
-\end{array}$ & $\begin{array}{r}0.03 \\
.51 \\
.49 \\
.07 \\
\hdashline-.\end{array}$ & $\begin{array}{r}0.14 \\
.64 \\
.34 \\
.06 \\
.05\end{array}$ & $\begin{array}{r}0.03 \\
.34 \\
.19 \\
.03 \\
.02\end{array}$ & $\begin{array}{l}0.32 \\
.11 \\
.04 \\
.05\end{array}$ & $\begin{array}{r}0.38 \\
.10 \\
.02 \\
.04\end{array}$ & $\begin{array}{r}0.05 \\
.38 \\
.19 \\
.05 \\
.08\end{array}$ & $\begin{array}{r}0.01 \\
.24 \\
.11 \\
.06 \\
.03\end{array}$ & $\begin{array}{r}0.08 \\
.06 \\
.04\end{array}$ & $\begin{array}{l}0.07 \\
.03 \\
.03\end{array}$ & $\begin{array}{l}0.12 \\
.51 \\
.12 \\
.08 \\
.10\end{array}$ & $\begin{array}{r}0.04 \\
.31 \\
.08 \\
.05 \\
.04\end{array}$ & $\begin{array}{c}0.35 \\
.04 \\
.05\end{array}$ & \begin{tabular}{c}
0.34 \\
\hdashline .03 \\
.04
\end{tabular} & $\begin{array}{l}0.04 \\
.51 \\
.18 \\
.08 \\
.09\end{array}$ & $\begin{array}{r}0.01 \\
.28 \\
.07 \\
.06 \\
.02\end{array}$ \\
\hline
\end{tabular}

1 See table 1 for names of soils.

2 See table 3 for names of materials.

The table shows that the antimonial lead lost weight at higher rates in 74 percent of the tests and that the refined lead lost weight more slowly than the chemical lead in 95 percent of the tests. These data confirm the experiences of other investigators who found that impurities or alloying elements tend to accelerate the corrosion of lead.

\section{CORROSION OF COPPER AND ALLOYS OF COPPER}

Brass in the form of cocks and valves has been used underground for many years. More recently copper and brass have been used for service pipe and, in some instances, for small distribution mains.

The copper-rich alloys used in this investigation are listed in table 3. Table 7 gives the corrosion data obtained from the specimens in 42 soils. As a rule two specimens of each material were removed from each location, but in a few cases one or more of the specimens were not found. Usually the loss of weight of these two specimens did not differ greatly, but in some cases one showed a loss 50 percent greater than the other.

These averages suggest that the $\operatorname{rod} A$, which is an alloy of copper, zinc, lead, and nickel, is less resistant to soil action than the alloy of copper, aluminum, and iron.

The copper-zinc-lead-nickel alloy $(A)$ was most susceptible to attack. The forged brass alloy $(M e)$ corroded more rapidly than the alloy $M$. Both were relatively susceptible to attack. 
TABLE 7-Corrosion of copper-rich alloys ${ }^{1}$ exposed 8 years

$M=$ Shallow metal attack, ro ughening of the surface but no definite pitting.

$P=$ Definite pitting, no pits greater than 6 mils.

$U=$ Unaffected by corrosion.

$S=$ Severe uniform corrosion, impossible to measure penetration because of even destruction of surface. $D=$ Selective corrosion such as dezincification over large areas.

$d=$ Selective corrosion in spots.

$Z=$ Destroyed by dezincification.

\begin{tabular}{|c|c|c|c|c|c|c|c|c|c|c|c|}
\hline \multirow{3}{*}{ Soil 8} & \multicolumn{6}{|c|}{ A verage rate of loss of weight $\left(\mathrm{oz} / \mathrm{ft}^{2} / \mathrm{yr}\right)$} & \multicolumn{5}{|c|}{ Condition of surface and pit depth 3} \\
\hline & \multicolumn{2}{|c|}{ Copper pipe } & \multicolumn{2}{|c|}{ Brass } & \multirow{2}{*}{$\begin{array}{c}\mathrm{Cu}-\mathrm{Zn}- \\
\mathrm{Ni} \\
\operatorname{rod} A\end{array}$} & \multirow{2}{*}{$\begin{array}{c}\mathrm{Cu}-\mathrm{Al}- \\
\mathrm{Fe} \\
\operatorname{rod} N\end{array}$} & \multicolumn{2}{|c|}{ Copper pipe } & \multirow{2}{*}{$\begin{array}{c}\text { Brass } \\
\text { pipe } B\end{array}$} & \multirow{2}{*}{$\begin{array}{c}\mathrm{Cu}-\mathrm{Zn}- \\
\mathrm{Ni} \\
\operatorname{rod} A\end{array}$} & \multirow{2}{*}{$\begin{array}{c}\mathrm{Cu}-\mathrm{Al}- \\
\mathrm{F} \theta \\
\operatorname{rod} N\end{array}$} \\
\hline & $M$ & $P$ & Pipe $B$ & Ell $M e$ & & & $M$ & $P$ & & & \\
\hline & $\begin{array}{r}0.060 \\
.073 \\
.027 \\
.019 \\
.068\end{array}$ & $\begin{array}{l}0.063 \\
.016 \\
.029 \\
.019 \\
.087\end{array}$ & $\begin{array}{r}0.097 \\
.080 \\
.074 \\
.144 \\
.054\end{array}$ & $\begin{array}{r}0.185 \\
.228 \\
.109 \\
\hdashline .525\end{array}$ & $\begin{array}{l}0.157 \\
.131 \\
.156 \\
.176 \\
.141\end{array}$ & $\begin{array}{r}0.057 \\
.046 \\
.063 \\
.070 \\
.061\end{array}$ & $\begin{array}{c}1.5 \\
P \\
P \\
1.3 \\
M\end{array}$ & $\begin{array}{l}P \\
P \\
P \\
M \\
M\end{array}$ & $\begin{array}{c}M, D \\
P, D \\
1,2, d \\
P, D \\
M, D\end{array}$ & $\begin{array}{c}P \\
P \\
1.2 \\
1.3 \\
P\end{array}$ & $\begin{array}{c}M, D \\
M, d \\
D \\
D \\
D\end{array}$ \\
\hline 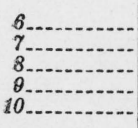 & $\begin{array}{l}.055 \\
.039 \\
.024 \\
.041 \\
.100\end{array}$ & $\begin{array}{l}.025 \\
.052 \\
.019 \\
.041 \\
.103\end{array}$ & $\begin{array}{l}.039 \\
.171 \\
.018 \\
.105 \\
.182\end{array}$ & $\begin{array}{r}.033 \\
.319 \\
.112 \\
.198\end{array}$ & $\begin{array}{l}.070 \\
.307 \\
.136 \\
.116 \\
.231\end{array}$ & $\begin{array}{l}.0025 \\
.044 \\
.026 \\
.0082 \\
.036\end{array}$ & $\begin{array}{c}M \\
P \\
1.5 \\
P \\
P\end{array}$ & $\begin{array}{c}M \\
P \\
1.3 \\
P \\
P\end{array}$ & $\mid \begin{array}{c}M, d \\
P, D \\
M, d \\
P, D \\
1.3, D\end{array}$ & $\begin{array}{c}P \\
1.2 \\
1.5 \\
P \\
1.0\end{array}$ & $\begin{array}{c}U \\
M, D \\
1.9, d \\
M \\
D\end{array}$ \\
\hline 2 & $\begin{array}{l}.312 \\
.023 \\
.040 \\
.013 \\
.057\end{array}$ & $\begin{array}{l}.278 \\
.031 \\
.025 \\
.016 \\
.058\end{array}$ & $\begin{array}{l}.222 \\
.101 \\
.044 \\
.030 \\
.170\end{array}$ & $\begin{array}{l}.024 \\
.089 \\
.166\end{array}$ & $\begin{array}{l}.199 \\
.012 \\
.096 \\
.045 \\
.234\end{array}$ & $\begin{array}{l}.090 \\
.028 \\
.017 \\
.026 \\
.093\end{array}$ & $\begin{array}{c}1.5 \\
P \\
P \\
M \\
3.3\end{array}$ & $\begin{array}{c}S \\
P \\
\stackrel{9}{M} \\
1.9\end{array}$ & $\begin{array}{c}P, D \\
M, D \\
P, d \\
D, D \\
1.3, D\end{array}$ & $\begin{array}{c}M \\
M \\
1.9 \\
d \\
.9\end{array}$ & $\begin{array}{c}P, d \\
M, d \\
M, d \\
\quad d d \\
d\end{array}$ \\
\hline $82 \ldots$ & $\begin{array}{l}.037 \\
.0076 \\
.039 \\
.042 \\
.068\end{array}$ & $\begin{array}{l}.040 \\
.0077 \\
.040 \\
.039 \\
.070\end{array}$ & $\begin{array}{l}.059 \\
.021 \\
.122 \\
.044 \\
.195\end{array}$ & $\begin{array}{l}.257 \\
.070 \\
.067 \\
.193 \\
.283\end{array}$ & $\begin{array}{l}.108 \\
.044 \\
.165 \\
.138 \\
.277\end{array}$ & $\begin{array}{l}.049 \\
.013 \\
.027 \\
.044 \\
.075\end{array}$ & $\begin{array}{c}M \\
U \\
1.1 \\
1.5 \\
1.9\end{array}$ & $\begin{array}{c}M \\
M \\
P \\
1.2 \\
1.0\end{array}$ & $\begin{array}{c}M, d \\
M, d \\
P, D \\
P, d \\
1.1, D\end{array}$ & $\begin{array}{l}P \\
1.3 \\
1.3 \\
P \\
P\end{array}$ & $\begin{array}{c}D \\
U \\
M, d \\
D \\
M, D\end{array}$ \\
\hline $\begin{array}{l}26-- \\
27=-\end{array}$ & $\begin{array}{l}.118 \\
.017 \\
.012 \\
.010 \\
.019\end{array}$ & $\begin{array}{l}.135 \\
.019 \\
.011 \\
.011 \\
.031\end{array}$ & $\begin{array}{l}.752 \\
.022 \\
.051 \\
.048 \\
.050\end{array}$ & $\begin{array}{r}1.853 \\
.045 \\
.142 \\
.101\end{array}$ & $\begin{array}{l}.288 \\
.040 \\
.126 \\
.103 \\
.121\end{array}$ & $\begin{array}{l}.169 \\
.021 \\
.043 \\
.026 \\
.032\end{array}$ & $\begin{array}{c}1.9 \\
M \\
P \\
U \\
P\end{array}$ & $\begin{array}{c}1.3 \\
M \\
U \\
M \\
M\end{array}$ & $\begin{array}{c}Z \\
U \\
P, D \\
M, D \\
M, D\end{array}$ & $\begin{array}{l}U \\
P \\
P \\
P \\
P\end{array}$ & $\begin{array}{c}D \\
D \\
D \\
1.9, d \\
D\end{array}$ \\
\hline $38-\ldots . .$. & $\begin{array}{l}.084 \\
.123 \\
.021 \\
.049 \\
.137\end{array}$ & $\begin{array}{l}.079 \\
.116 \\
.025 \\
.018 \\
.117\end{array}$ & $\begin{array}{l}.080 \\
.275 \\
.045 \\
.089 \\
.175\end{array}$ & $\begin{array}{l}.082 \\
.152 \\
.218\end{array}$ & $\begin{array}{l}.163 \\
.257 \\
.070 \\
.129 \\
.208\end{array}$ & $\begin{array}{l}.107 \\
.082 \\
.039 \\
.016 \\
.040\end{array}$ & $\begin{array}{c}P \\
P \\
M \\
U \\
.9\end{array}$ & $\begin{array}{c}P \\
P \\
P \\
M \\
1.0\end{array}$ & $\begin{array}{c}M, D \\
P, D \\
M, d \\
1.0, D \\
P, D\end{array}$ & $\begin{array}{c}P \\
1.9 \\
P \\
1.3 \\
1.3\end{array}$ & $\begin{array}{c}M, D \\
M, d \\
1.0 \\
d \\
M, d\end{array}$ \\
\hline $\begin{array}{l}34 \\
35 \\
36 \\
36 \\
38 \\
38\end{array}$ & $\begin{array}{l}.016 \\
.017 \\
.023 \\
.169 \\
.025\end{array}$ & $\begin{array}{l}.022 \\
.016 \\
.024 \\
.162 \\
.043\end{array}$ & $\begin{array}{l}.057 \\
.020 \\
.056 \\
.152 \\
.028\end{array}$ & $\begin{array}{l}.080 \\
.422 \\
.049 \\
.274 \\
.037\end{array}$ & $\begin{array}{l}.177 \\
.063 \\
.113 \\
.175 \\
.034\end{array}$ & $\begin{array}{l}.021 \\
.039 \\
.022 \\
.060 \\
.019\end{array}$ & $\begin{array}{c}M \\
M \\
P \\
1.8 \\
M\end{array}$ & $\begin{array}{c}P \\
P \\
P \\
1.3 \\
P\end{array}$ & $\begin{array}{c}M, D \\
D \\
1.3, d \\
P, D \\
M, d\end{array}$ & $\begin{array}{l}P \\
1.0 \\
1.3 \\
P \\
P\end{array}$ & $\underset{\substack{D \\
M, d \\
\underset{U}{U}, d}}{d}$ \\
\hline 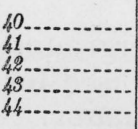 & $\begin{array}{l}.125 \\
.036 \\
.047 \\
.635 \\
.079\end{array}$ & $\begin{array}{l}.168 \\
.040 \\
.049 \\
.555 \\
.061\end{array}$ & $\begin{array}{l}.349 \\
.083 \\
.095 \\
.026 \\
.175\end{array}$ & $\begin{array}{l}.330 \\
.083 \\
.089 \\
.022 \\
-.--\end{array}$ & $\begin{array}{l}.385 \\
.155 \\
.154 \\
.007 \\
.248\end{array}$ & $\begin{array}{l}.092 \\
.020 \\
.057 \\
.022 \\
.026\end{array}$ & $\begin{array}{c}2.3 \\
P \\
P \\
S \\
P\end{array}$ & $\begin{array}{c}4.1 \\
M \\
1.1 \\
S \\
P\end{array}$ & $\begin{array}{c}1.8, D \\
9, D \\
P, D \\
M, d \\
1.3, D\end{array}$ & $\begin{array}{c}1.9 \\
P \\
1.9 \\
U \\
2.4\end{array}$ & $\begin{array}{c}d \\
d \\
P, D \\
2,3 \\
P, d\end{array}$ \\
\hline $45 \ldots$ & $\begin{array}{l}.033 \\
.052\end{array}$ & $\begin{array}{l}.030 \\
.0053\end{array}$ & $\begin{array}{l}.016 \\
.0031\end{array}$ & $\begin{array}{l}.214 \\
.027\end{array}$ & $\begin{array}{l}.081 \\
.0046\end{array}$ & $\begin{array}{l}.030 \\
.0038\end{array}$ & 1.0 & ${ }_{U}^{1.0}$ & $\stackrel{d}{D}$ & $\begin{array}{l}1.0 \\
M\end{array}$ & $\begin{array}{l}D \\
D\end{array}$ \\
\hline
\end{tabular}

1 See table 3 for identification of materials.

2 See table 2 for names of soils.

8 The letters indicate the condition of the worse of 2 specimens. The figures are rates of maximum penetration, in mils per year.

It is necessary to point out here the fact that brasses high in zinc sometimes undergo selective corrosion known as dezincification in which there is little or no pitting and a loss of strength and service life greater than is indicated by the loss of weight. Extreme cases of dezincification are shown in figure 3 . In most cases the specimens high in zinc were not pitted and no attempt was made to determine 


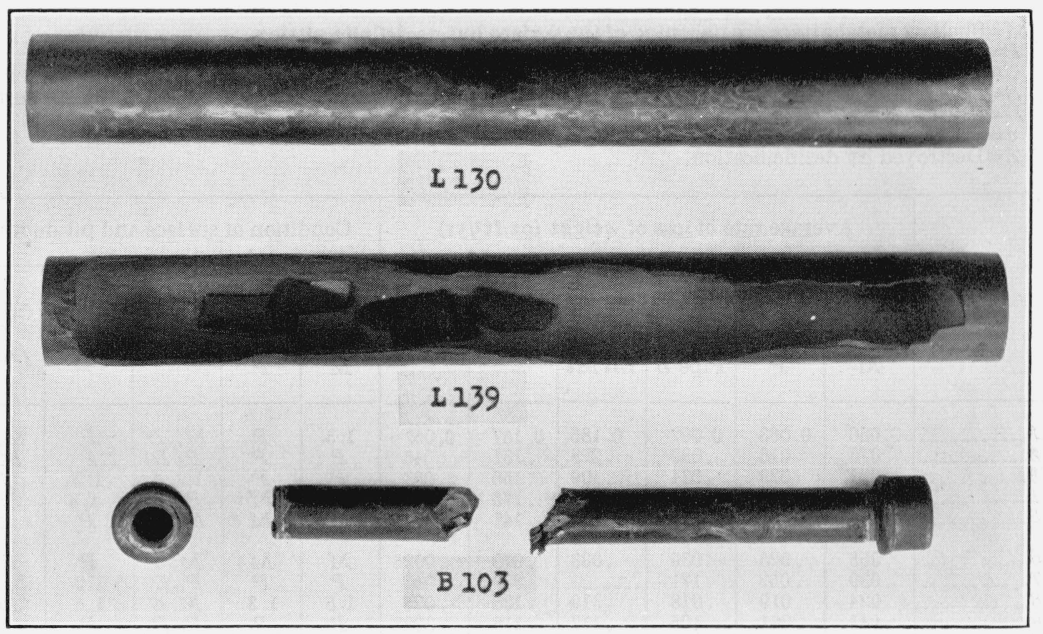

Figure 3.-Dezincification of Muntz metal.

$L 130$, Exposed for 2 years to an alkali soil; $L 139$, exposed 2 years to cinders; B103, exposed 10 years to Merced silt loam, an alkali soil.

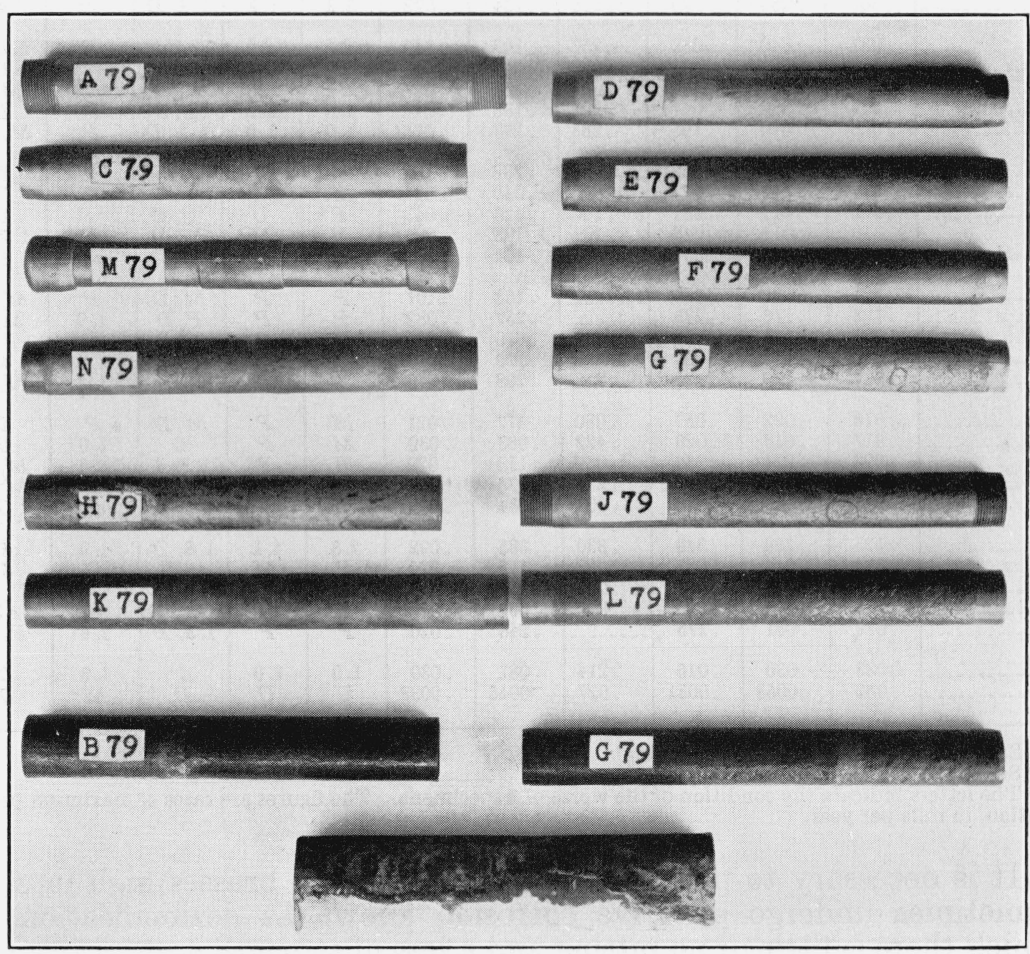

FiguRE 4.-Nonferrous specimens from a peat soil.

See table 3 for identification of the nonferrous materials. At the bottom of the figure specimen $B \gamma 9$ is wrought iron, G79 is cast iron, and the unnumbered specimen is a cement-asbestos pipe.

The lengths of the specimens are from 10 to 14 inches. 


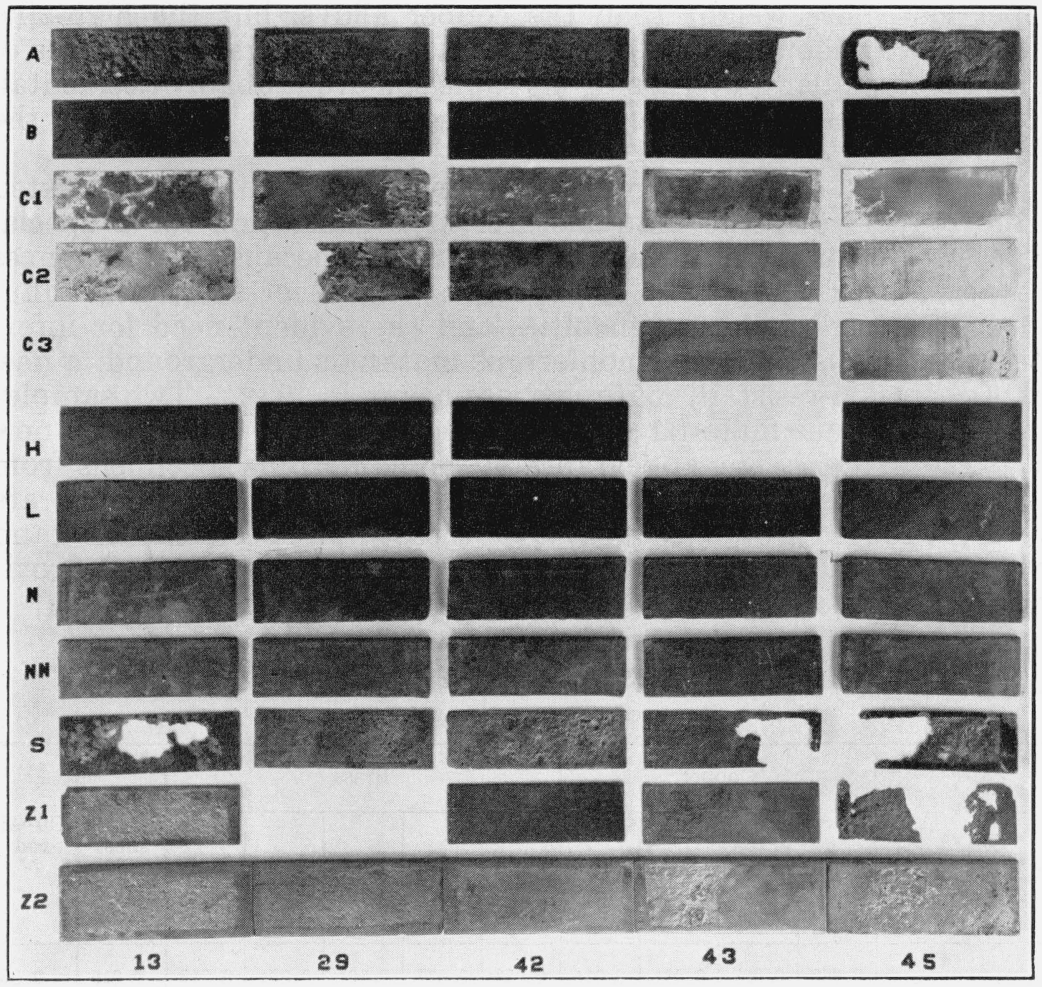

Figure 5.-Condition of miscellaneous specimens.

Conditions of miscellaneous specimens exposed to five soils for approximately 10 years. $A$, Open-hearth iron; $B$, brass; $C 1$, aluminum; $C 2, \mathrm{Al}-\mathrm{Mn}$ alloy; $C 3$, duralumin; $H$, copper; $L$, bronze; $N$, chemical lead; $N N$, refined lead; $S$, copper bearing steel; $Z 1$, rolled zinc; $Z 2$, cast zinc. The soils are as follows: 13 Hanford very fine sandy loam; 29, muck; 42, susquehanna clay; 43, tidal marsh; 45, unidentified soil containing sulfates. 
the depth of the dezincification. The worse of the two specimens at each locality is indicated in table 7, but in most cases the specimens of the same material did not differ greatly.

Six widely different soils were chosen from the original test sites for tests of materials which were not available in sufficient quantities to permit their burial at all test sites. Five of these soils are severely corrosive with respect to iron. Table 8 shows the rates of loss of weight for all the copper-alloy specimens removed from these soils. The figures are based on the losses of weight of two specimens. It will be noted that the rates of corrosion of all of the copper alloys are low except in soil 43 , a tidal marsh high in sulfides. In this soil copper lost more weight than the copper alloys, but the high-zine alloys showed some local dezincification. The differences in rates of corrosion of similar materials in the same soil are probably accidental. Such differences are characteristic of soil-corrosion data from the field.

Prior to 1932 such nonferrous specimens as were buried were tested at the request of some manufacturer or organization for a special purpose. Comparison of materials is difficult because of differences in exposed areas, durations of exposures and other accidental influences. Because of these difficulties and the evident need for information on the usefulness of nonferrous materials underground, a new test of corrosion-resistant materials was begun in 1932. Two samples of each nonferrous material were removed from each of 14 of the new test sites in 1934. The appearance of the nonferrous specimens from the peat soil is shown in figure 4. At the bottom of the figure are shown a wrought iron specimen, B79, a cast-iron specimen, $G^{7} 9$, and a specimen of a cement-asbestos pipe. The specimens are approximately 12 inches long.

TABLE 8.-Rates of loss of weight of copper alloys ${ }^{1}$ in 6 soils

[In ounces per square foot per year]

\begin{tabular}{|c|c|c|c|c|c|c|c|c|c|c|c|}
\hline \multirow{3}{*}{ Soil \& } & \multicolumn{4}{|c|}{ Copper } & \multicolumn{5}{|c|}{ Brass } & \multirow{3}{*}{$\begin{array}{c}\text { Bronze } \\
\text { sheet } \\
L\end{array}$} & \multirow{3}{*}{$\begin{array}{c}\mathrm{Cu}-\mathrm{Al} \\
\text { rod } \\
N\end{array}$} \\
\hline & \multicolumn{3}{|c|}{ Pipe } & \multirow{2}{*}{\begin{tabular}{|c} 
Sheet \\
$H$
\end{tabular}} & \multirow{2}{*}{$\underset{H}{\text { Pipe }}$} & \multirow{2}{*}{$\begin{array}{c}\text { Sheet } \\
B^{1}\end{array}$} & \multirow{2}{*}{$\underset{B}{\operatorname{Pipe}}$} & \multirow{2}{*}{$\begin{array}{l}\text { Ell } \\
M e\end{array}$} & \multirow{2}{*}{$\underset{A}{\operatorname{Rod}}$} & & \\
\hline & $E$ & $M$ & $P$ & & & & & & & & \\
\hline 24 & 0.052 & \begin{tabular}{|l|}
0.023 \\
.017
\end{tabular} & 0.031 & 0.015 & 0.022 & 0.077 & 0.101 & 0.024 & 0.012 & 0.015 & 0.028 \\
\hline 29 & .040 & .123 & .116 & .116 & .061 & .153 & .275 & & $\begin{array}{l}.257 \\
\end{array}$ & .131 & .082 \\
\hline $48-$ & .080 & .047 & .049 & .044 & .105 & .051 & .095 & .089 & .154 & .046 & .057 \\
\hline 45 & .028 & .033 & $\begin{array}{l}.050 \\
.030\end{array}$ & .015 & $\begin{array}{l}.070 \\
.020\end{array}$ & $\begin{array}{l}.010 \\
.074\end{array}$ & $\begin{array}{l}.020 \\
.016\end{array}$ & $\begin{array}{l}.022 \\
.214\end{array}$ & .007 & $\begin{array}{l}.460 \\
.049\end{array}$ & .030 \\
\hline
\end{tabular}

1 See table 3 for analyses of materials.

2 See table 1 for names of soils.

The average rates of loss of weight of the nonferrous specimens are given in table 9 and the conditions of the specimens are shown in table 10. In cases where specimens subjected to similar conditions differed, the worse condition was recorded.

Because rates of corrosion frequently change with time, and because not many specimens have been examined, definite conclusions should not be drawn from these tables. In general, tables 9 and 10 confirm the data in tables 7 and 8 . It should be remembered that cinders from other sources may differ considerably from those used at site 67 . 
Since data on the corrosion of copper appear in several tables discussion of the effects of soils on this material has been withheld until all of these tables have been presented. From these tables it will be seen that copper corrodes most rapidly in soils containing sulfides. The scale which is formed under these conditions does not appear to have much protective value. Copper corrodes rapidly also in some cinders, perhaps because they also contained sulfides. This should be kept in mind when light-weight pipe is used in city streets containing cinder fills.

In most soils, however, the rate of corrosion of copper and its alloys is much lower than that for ferrous materials, as will be seen by comparing the data in tables $7,8,9$, and 10 with the last two columns of table 4. It is interesting to note in tables $7,8,9$, and 10 that in the tidal marshes (soils 43 and 63), the Muntz metal pipe appears definitely superior to the copper pipe.

TABLE 9.- Rates ${ }^{1}$ of loss of weight of nonferrous specimens exposed approximately 2 years

\begin{tabular}{|c|c|c|c|c|c|c|c|c|c|c|c|}
\hline Soil 2 & $\begin{array}{c}\text { Tough } \\
\text { pitch } \\
\mathrm{Cu} \\
\\
\text { C }\end{array}$ & $\begin{array}{c}\text { Deoxi- } \\
\text { dized } \\
\text { cop- } \\
\text { per }\end{array}$ & $\begin{array}{c}\text { Red } \\
\text { brass } \\
\text { F }\end{array}$ & $\begin{array}{c}\text { Admir- } \\
\text { alty } \\
\text { metal } \\
H\end{array}$ & $\begin{array}{c}\text { Two } \\
\text { and one } \\
\text { leaded } \\
\text { brass } \\
K\end{array}$ & $\begin{array}{c}\text { Brass- } \\
66 \% \\
\text { Cu; } \\
33 \% \mathrm{Zn} \\
\boldsymbol{J}\end{array}$ & $\begin{array}{c}\text { Muntz } \\
\text { metal } \\
L\end{array}$ & $\begin{array}{c}\text { Bronze- } \\
97 \% \mathrm{Cu} ; \\
1 \% \mathrm{Si} ; \\
1.8 \% \mathrm{Sn} \\
E\end{array}$ & $\begin{array}{c}\text { Alloy- } \\
98 \% \\
\mathrm{Cu} ; \\
1.5 \% \mathrm{Si} \\
N\end{array}$ & $\begin{array}{c}\text { Alloy- } \\
95 \% \\
\text { Cu; } \\
3 \% \text { Si } \\
D\end{array}$ & $\begin{array}{c}\text { Alloy- } \\
75 \% \\
\text { Cu; } \\
20 \% \mathrm{Ni} \text {, } \\
5 \% \mathrm{Zn} \\
G\end{array}$ \\
\hline $\begin{array}{l}51 \ldots \\
59 \ldots \\
55 \ldots \\
56 \ldots \\
57 \ldots\end{array}$ & $\begin{array}{l}0.21 \\
.062 \\
.072 \\
.059 \\
.0036\end{array}$ & $\begin{array}{l}0.20 \\
.061 \\
.075 \\
.051 \\
.0062\end{array}$ & $\begin{array}{l}0.17 \\
.060 \\
.068 \\
.054 \\
.0054\end{array}$ & $\begin{array}{l}0.16 \\
.070 \\
.079 \\
.040 \\
.0061\end{array}$ & $\begin{array}{l}0.085 \\
.13 \\
.11 \\
.080 \\
.041\end{array}$ & $\begin{array}{l}0.17 \\
.052 \\
.094 \\
.042 \\
.041\end{array}$ & $\begin{array}{l}0.35 \\
.097 \\
.10 \\
.072 \\
.24\end{array}$ & $\begin{array}{l}0.26 \\
.12 \\
.16 \\
.12 \\
.031\end{array}$ & $\begin{array}{c}0.18 \\
.097 \\
.076 \\
.075 \\
.012\end{array}$ & $\begin{array}{l}0.23 \\
.090 \\
.080 \\
.050 \\
.012\end{array}$ & $\begin{array}{l}0.14 \\
.059 \\
.061 \\
.033 \\
.0099\end{array}$ \\
\hline $\begin{array}{l}68 \ldots \\
60 \ldots \\
61 \ldots \\
62 \ldots \\
63 \ldots\end{array}$ & $\begin{array}{l}.066 \\
.71 \\
.10 \\
.080 \\
.64\end{array}$ & $\begin{array}{l}.082 \\
.76 \\
.062 \\
.079 \\
.55\end{array}$ & $\begin{array}{l}.061 \\
.76 \\
.12 \\
.077 \\
.27\end{array}$ & $\begin{array}{l}.096 \\
.59 \\
.18 \\
.11 \\
.12\end{array}$ & $\begin{array}{l}.13 \\
.59 \\
.12 \\
.15 \\
.23\end{array}$ & $\begin{array}{l}.11 \\
.89 \\
.12 \\
.12 \\
.021\end{array}$ & $\begin{array}{l}.10 \\
.90 \\
.17 \\
.17 \\
.069\end{array}$ & $\begin{array}{l}.094 \\
.84 \\
.20 \\
.17 \\
.57\end{array}$ & $\begin{array}{l}.054 \\
.68 \\
.14 \\
.11 \\
.80\end{array}$ & $\begin{array}{l}.056 \\
.69 \\
.14 \\
.13 \\
.61\end{array}$ & $\begin{array}{l}.074 \\
.72 \\
.13 \\
.091 \\
.32\end{array}$ \\
\hline $\begin{array}{l}64 \ldots \\
65 \ldots \\
66 \ldots \\
67 \ldots\end{array}$ & $\begin{array}{l}.35 \\
.26 \\
.055 \\
1.56\end{array}$ & $\begin{array}{r}.74 \\
.90 \\
.15 \\
1.97\end{array}$ & $\begin{array}{l}.17 \\
.27 \\
.092 \\
1.66\end{array}$ & $\begin{array}{r}.13 \\
.16 \\
.12 \\
2.75\end{array}$ & $\begin{array}{c}.12 \\
.072 \\
.13 \\
3.39\end{array}$ & $\begin{array}{r}.30 \\
.72 \\
.18 \\
8.20\end{array}$ & $\begin{array}{l}2.11 \\
1.27 \\
\left(\dot{4}^{33}\right.\end{array}$ & $\begin{array}{r}.41 \\
.25 \\
.20 \\
1.61\end{array}$ & $\begin{array}{r}.72 \\
.58 \\
.10 \\
2.74\end{array}$ & $\begin{array}{r}.35 \\
.58 \\
.11 \\
2.09\end{array}$ & $\begin{array}{r}.041 \\
.089 \\
.11 \\
1.03\end{array}$ \\
\hline
\end{tabular}

1 Average for two specimens in ounces per square foot per year.

2 See table 1 for names of soils.

See table 3 for analyses of materials.

- Destroyed.

Sufficient data are not available for plotting the relation of the period of exposure to the corrosion for individual soils. A comparison of the average rates of loss of weight for the materials listed in table 7 with corresponding data for 4-year-old specimens indicates little or no change in the rates of corrosion. This may indicate that the corrosion-resisting properties of copper are due to low electrochemical potential rather than to the formation of protective films, or that such films as are formed reach their maximum effectiveness very soon after the material is exposed to soil.

\section{CORROSION OF ALUMINUM AND ZINC}

Data on specimens of aluminum and zinc removed in 1934 are shown in table 11, together with those for other specimens of the same dimensions and periods of exposure. The appearance of these specimens is shown in figure 5 . (Specimens $C 1, C 2$, and $C 3$.) The blank spaces represent lost specimens. In the case of the aluminum 
TABLE 10.-Surface condition ${ }^{1}$ and rate of penetration of nonferrous specimens exposed approximately 2 years

$M=$ Shallow metal attack, roughening of surface but no definite pitting.

$P=$ Definite pitting but no pits greater than 6 mils.

$U=$ Apparently unaffected by corrosion.

$S=$ Severe uniform corrosion; impossible to measure penetration because of uniform destruction of surface. $D=$ Selective corrosion over large areas, i. e., several square inches per square foot.

$d=$ Selective corrosion in small spots.

$Z=$ Destroyed by dezincification.

\begin{tabular}{|c|c|c|c|c|c|c|c|c|c|c|c|}
\hline Soil ${ }^{2}$ & $\begin{array}{c}\text { Tough } \\
\text { pitch } \\
\text { cop- } \\
\text { per } \\
\\
C\end{array}$ & $\begin{array}{l}\text { Deoxi- } \\
\text { dized } \\
\text { cop- } \\
\text { per }^{3} \\
A\end{array}$ & $\begin{array}{c}\text { Red } \\
\text { brass } \\
\text { F }\end{array}$ & $\begin{array}{c}\text { Admir- } \\
\text { alty } \\
\text { metal }\end{array}$ & $\begin{array}{c}\text { Two } \\
\text { and one } \\
\text { leaded } \\
\text { brass } \\
K\end{array}$ & $\begin{array}{c}\text { Brass- } \\
66 \% \\
\mathrm{Cu} \\
33 \% \mathrm{Zn} \\
\boldsymbol{J}\end{array}$ & $\begin{array}{c}\text { Muntz } \\
\text { metal } \\
\text { L }\end{array}$ & $\begin{array}{c}\text { Bronze- } \\
97 \% \mathrm{Cu} ; \\
1 \% \mathrm{Si} ; \\
1.8 \% \mathrm{Sn} \\
\text { E }\end{array}$ & $\begin{array}{c}\text { Alloy- } \\
98 \% \\
\mathrm{Cu} \\
1.5 \% \mathrm{Si} \\
N\end{array}$ & $\begin{array}{c}\text { Alloy }- \\
95 \% \\
\text { Cu; } \\
3 \% \text { Si } \\
D\end{array}$ & $\begin{array}{c}\text { Alloy- } \\
75 \% \\
\text { Cu; } \\
20 \% \mathrm{Ni} ; \\
5 \% \mathrm{Zn} \\
G\end{array}$ \\
\hline .... & $\begin{array}{l}M \\
M \\
P^{3} \\
M \\
M\end{array}$ & $\begin{array}{l}M \\
P \\
P \\
M \\
U\end{array}$ & $\begin{array}{c}M \\
4.1 \\
6.3 \\
M^{3} \\
4.2\end{array}$ & $\begin{array}{c}M, d \\
6.1, d \\
11.6 \\
M, d \\
P, d\end{array}$ & $\begin{array}{c}M, D \\
M, d \\
M, d \\
M, d \\
M\end{array}$ & $\begin{array}{r}M, D \\
5.1, d \\
5.8 \\
M, d \\
M, d\end{array}$ & $\begin{array}{c}M, d \\
P, d \\
5.3, d \\
d \\
M, d\end{array}$ & $\begin{array}{r}P^{\prime} \\
6.6 \\
7.4 \\
6.5 \\
12.6\end{array}$ & $\begin{array}{l}M \\
P \\
P \\
P \\
M\end{array}$ & $\begin{array}{l}M \\
P \\
5.8 \\
M \\
M\end{array}$ & $\begin{array}{c}d, M \\
P, d \\
4.3, d \\
M, d \\
d\end{array}$ \\
\hline 1 & $\begin{array}{l}P \\
P \\
P \\
P \\
4.3\end{array}$ & $\begin{array}{c}M \\
\text { 5. }, S \\
P \\
4.1 \\
M\end{array}$ & $\begin{array}{l}M \\
7.8 \\
P \\
5.2 \\
P\end{array}$ & $\begin{array}{c}P, d \\
5.2 \\
8.4, d \\
8.8 \\
M\end{array}$ & $\begin{array}{l}M, d \\
P, d \\
P, d \\
P, d \\
\dot{M}\end{array}$ & $\begin{array}{c}M, d \\
9.4 \\
10.5, d \\
P, d \\
P\end{array}$ & $\begin{array}{c}P, d \\
7.8, d \\
P, d \\
P, d \\
\dot{M}\end{array}$ & $\begin{array}{r}6.0 \\
14.1 \\
P \\
9.9 \\
13.4\end{array}$ & $\begin{array}{l}M \\
6.8 \\
P \\
P \\
P\end{array}$ & $\begin{array}{l}M \\
P \\
M \\
\stackrel{4}{P} .7\end{array}$ & $\begin{array}{l}7.0 \\
P .3 \\
P, d \\
P, d\end{array}$ \\
\hline $\begin{array}{l}64 \ldots \\
65 \\
66 \ldots \\
67 \\
67 .\end{array}$ & $\begin{array}{c}5.8 \\
P \\
P \\
17.3\end{array}$ & \begin{tabular}{l}
\multicolumn{1}{c}{$S$} \\
$S$ \\
6.3 \\
21.8
\end{tabular} & $\begin{array}{r}12.0 \\
5.2 \\
P \\
14.9\end{array}$ & $\begin{array}{c}13.1, d \\
18.3 \\
M, d \\
25.7\end{array}$ & $\begin{array}{c}M \\
M, d \\
M, d \\
29.2\end{array}$ & $\begin{array}{l}P, d \\
M, d \\
M, d \\
Z\end{array}$ & $\begin{array}{l}P, D \\
M, D \\
P, d^{3} \\
Z\end{array}$ & $\begin{array}{r}11.0 \\
12.0 \\
6.3 \\
21.2\end{array}$ & \begin{tabular}{r|}
5.8 \\
4.2 \\
9.4 \\
23.2
\end{tabular} & $\begin{array}{l}13.1 \\
P \\
P \\
17.3\end{array}$ & $\begin{array}{c}P \\
P \\
M, d \\
12.1\end{array}$ \\
\hline
\end{tabular}

1 Condition or rate of maximum penetration on worse of 2 specimens; tigures are in mils per year.

2 See table 1 for names of soils.

a One specimen only.

alloys the loss was due in most cases to the almost complete destruction of the specimens. Table 11 is comparable with similar tables in earlier reports. ${ }^{8}$

\section{TABLE 11.-Rates of loss of weight and penetration of miscellaneous metals and alloys buried approximately 10 years}

$P=$ Definite pitting, no pits greater than 6 mils.

$S=$ Severe surface corrosion, impossible to measure penetration because of even destruction of surface. $M=$ Shallow metal attack, roughening of surface but no definite pitting.

$D=$ Dezincification over large areas.

$d=$ Dezincification in spots.

$f=$ Failure of 1 or more holes.

\begin{tabular}{|c|c|c|c|c|c|c|c|c|c|c|}
\hline \multirow{2}{*}{ Material b } & \multicolumn{2}{|c|}{ Soil 13 a } & \multicolumn{2}{|c|}{ Soil 29} & \multicolumn{2}{|c|}{ Soil 42} & \multicolumn{2}{|c|}{ Soil 49} & \multicolumn{2}{|c|}{ Soil 45} \\
\hline & Loss $c$ & Pits $d$ & Loss & Pits & Loss & Pits & Loss & Pits & Loss & Pits \\
\hline $\begin{array}{l}N N \text {, refined lead } \\
N, \text { chemical lead } \\
H \text {, eopper }-. . \\
B \text {, brass } \\
L \text {, bronze. }\end{array}$ & $\begin{array}{l}0.010 \\
.037 \\
.015 \\
.077 \\
.015\end{array}$ & $\begin{array}{c}1.1 \\
1.7 \\
M \\
M, D \\
1.1\end{array}$ & $\begin{array}{l}0.28 \\
.51 \\
.12 \\
.15 \\
.13\end{array}$ & $\begin{array}{l}1.4 \\
1.3 \\
S \\
P \\
5.5\end{array}$ & $\begin{array}{l}0.068 \\
.18 \\
.044 \\
.051 \\
.046\end{array}$ & $\begin{array}{l}P \\
2.5 \\
P \\
M, D \\
M\end{array}$ & $\begin{array}{l}0.062 \\
.076 \\
.010 \\
.46\end{array}$ & $\begin{array}{r}0.9 \\
1.2 \\
M, d \\
1.1\end{array}$ & $\begin{array}{l}0.020 \\
.088 \\
.015 \\
.010 \\
.049\end{array}$ & $\begin{array}{c}1.1 \\
P_{M, 8}^{1.8} \\
3.1\end{array}$ \\
\hline $\begin{array}{l}Z 1 \text {, sheet zinc- } \\
Z 2 \text {, cast zinc-... } \\
P \text {, sheet zinc_. } \\
C 1 \text {, aluminum } \\
C 2, \mathrm{Al}-\mathrm{Mn} \text {-alloy }\end{array}$ & $\begin{array}{l}.35 \\
.34 \\
.19 \\
.009 \\
.038\end{array}$ & $\begin{array}{l}4.0 \\
7.0 \\
5.2 \\
2.1 \\
f\end{array}$ & $\begin{array}{l}.46 \\
.53 \\
.38 \\
f \\
.096\end{array}$ & $\begin{array}{l}3.9 \\
5.5 \\
f \\
f\end{array}$ & $\begin{array}{l}.085 \\
.078 \\
.11 \\
.035 \\
.020\end{array}$ & $\begin{array}{l}1.7 \\
1.8 \\
2.0 \\
f \\
1.4\end{array}$ & $\begin{array}{l}.23 \\
.22 \\
.45 \\
.016 \\
.021\end{array}$ & $\begin{array}{l}3.3 \\
6.8 \\
3.7 \\
P \\
1.3\end{array}$ & $\begin{array}{l}f \\
.84 \\
f \\
.047 \\
.031\end{array}$ & $\begin{array}{l}f \\
f .8 \\
f \\
1.9\end{array}$ \\
\hline $\begin{array}{l}C s, \text { Duralumin } \\
A \text {, open-hearth iron..... } \\
S \text {, steel }+0.2 \% \mathrm{Cu}\end{array}$ & .98 & ${ }_{f}^{f}$ & $\begin{array}{l}.58 \\
.69\end{array}$ & ${ }_{f}^{6.2}$ & $\begin{array}{l}.14 \\
.56 \\
.54\end{array}$ & $\begin{array}{l}f \\
7.0 \\
5.9\end{array}$ & $\begin{array}{l}.014 \\
f \\
f\end{array}$ & $\begin{array}{c}M \\
f \\
f\end{array}$ & $\begin{array}{l}f \\
f\end{array}$ & $\begin{array}{l}f \\
f\end{array}$ \\
\hline
\end{tabular}

a See table 1 for names of soils.

c Loss is given in ounces per square foot per year.

$b$ See table 3 for names and analyses of materials. $\quad d$ Rate of maximum penetration in mils per year.

8 See table 20, Tech. Pap. T368; table 8, Research Pap. RP359; and table 12, Research Pap. RP368 References to these papers have been made in earlier parts of this report. 
Figure 6 shows the relation of the average maximum penetration to the duration of exposure of zinc specimens to five soils. Each point is based on the average of the deepest pits on each of two specimens. In two of these soils the rates of penetration appear to increase with the period of exposure.

Table 11, as well as similar tables previously published, ${ }^{9}$ shows that the purer zinc (hearth refined) corrodes less rapidly than the zinc which contains more impurities.

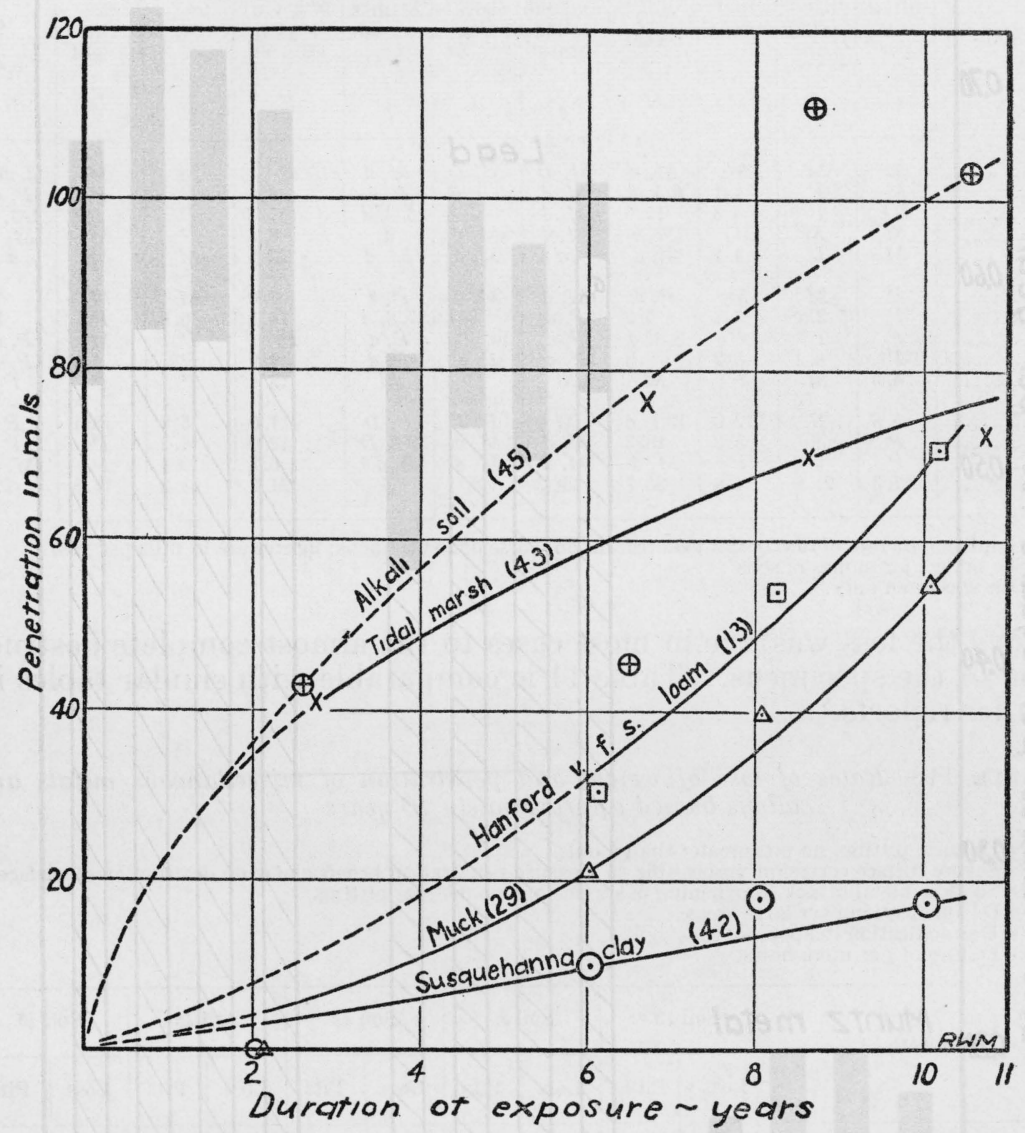

FrguRe 6.-Relation of the maximum penetration of zinc to the duration of exposure.

Under some circumstances the corrosion of the aluminum and aluminum-manganese alloy occurs mostly beneath the surface of the metal which is raised to form blisters beneath which a white powder is found.

It was not practicable to remove all of this powder without destroying some of the uncorroded metal and for this reason the losses of weight for the above mentioned materials as given in table 11 are inaccurate. They show, however, in a general way at least, the relative corrosiveness of the soils with respect to these materials. Since, as

\footnotetext{
' p. 544 Tech. Paper BS T368; p. 594, Research Paper RP359; p. 138, Research Paper RP638.
} 
has been shown, soils differ greatly in many ways, general conclusions as to the usefulness of thin aluminum sheet underground should not be drawn. The data indicate that the effect of the soil on the aluminum alloy should be investigated before the material is used underground.

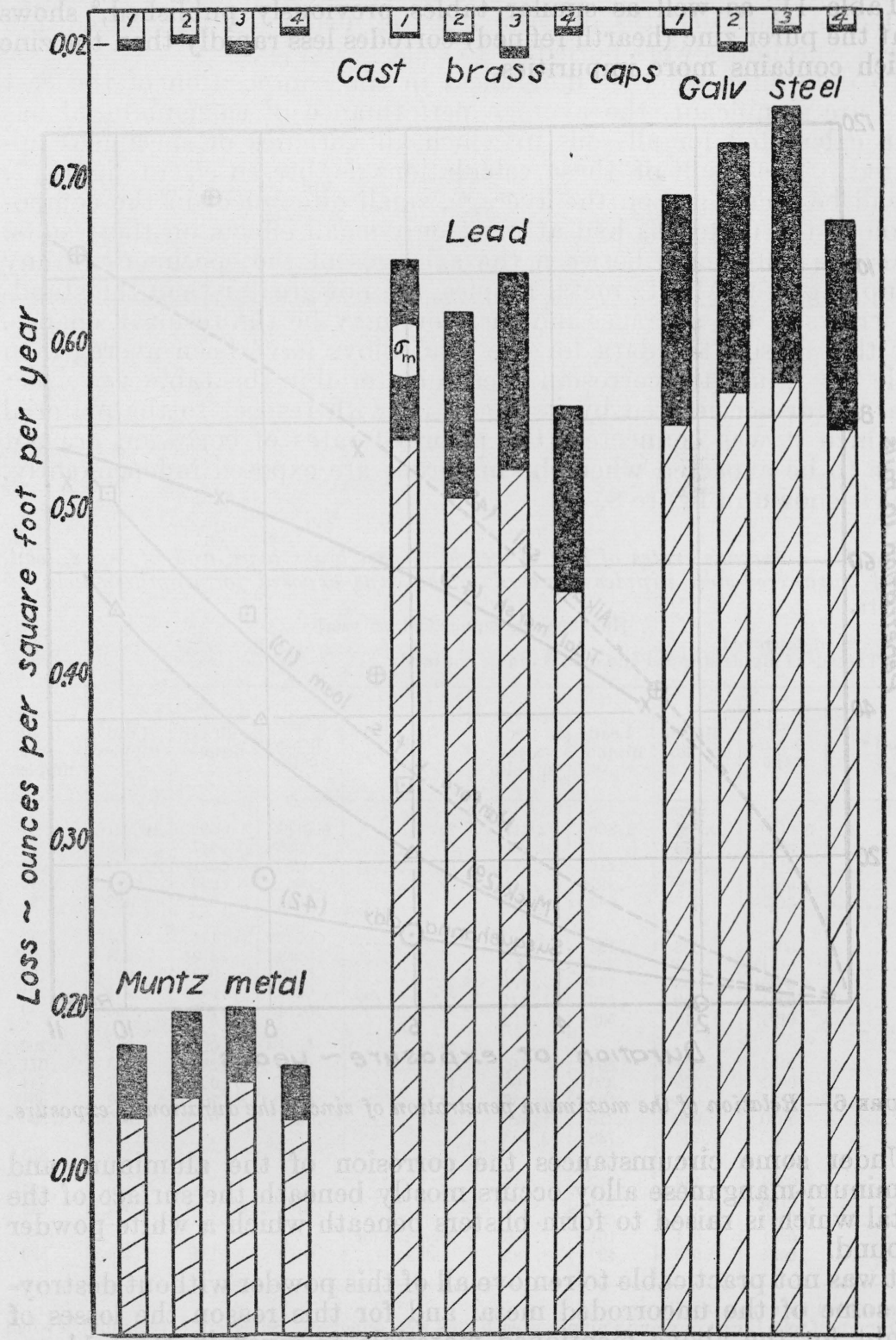

FIGURE 7.-Average rates of corrosion of cast-brass fittings and attached nipples in 15 soils.

At the top of the figure are shown the average rates of corrosion of four cast-copper alloys in the form of caps. Below are the rates of corrosion of the nipples attached to each variety of cast cap. See table 3 for analyses of materials. The solid ends of the column show the standard errors, $\sigma_{\mathrm{m}}$, of the averages. 


\section{EFFECT OF INTERCONNECTING DIFFERENT METALS}

Several experiments have been undertaken to determine the effect of placing two metals in contact under several soil conditions. The earliest of these in the National Bureau of Standards soil-corrosion investigation consisted of four varieties of cast-brass alloys each connected to short lengths of Muntz metal, lead, and galvanized-iron pipe. Specimens were buried in 45 soils.

To determine whether differences in the composition of the cast caps are significant, the average performance of each material has been calculated for all soils in which all varieties of specimens appeared. The result of these calculations is presented in figure 7 . It will be seen that, on the average, small differences in the composition of the materials had at most only small effects on the results. Thus the differences between the averages of the specimens in any group, e.g., the Muntz metal nipples, are not greater than the standard errors of the averages and therefore may be the result of chance. For this reason the data for the four alloys have been averaged in table 12. Since the corrosion of each material in this table was either retarded or accelerated by its potential with respect to the material to which it was connected, the recorded rates of corrosion are not those to be expected when the materials are exposed independently. This is shown in figure 8.

TABLE 12.-Average ${ }^{1}$ rates of loss of weight of cast brass caps, and of brass, lead, and galvanized-steel nipples attached to the caps exposed for approximately 10 years.

$f=$ Specimen destroyed.

[In ounces per square foot per year]

(1) = Threads of nipple stripped and data could be not used.

\begin{tabular}{|c|c|c|c|c|c|c|c|c|c|}
\hline Soil - & $\begin{array}{l}\text { Cast- } \\
\text { brass } \\
\text { caps }\end{array}$ & $\begin{array}{c}\text { Brass } \\
\text { nipples }\end{array}$ & $\begin{array}{c}\text { Lead } \\
\text { nipples }\end{array}$ & $\begin{array}{l}\text { Galvan- } \\
\text { ized } \\
\text { steel } \\
\text { nipples }\end{array}$ & Soil a & $\begin{array}{l}\text { Cast- } \\
\text { brass } \\
\text { caps }\end{array}$ & $\begin{array}{c}\text { Brass } \\
\text { nipples }\end{array}$ & $\begin{array}{c}\text { Lead } \\
\text { nipples }\end{array}$ & $\begin{array}{l}\text { Galvan- } \\
\text { ized } \\
\text { steel } \\
\text { nipples }\end{array}$ \\
\hline $\begin{array}{l}1 \ldots- \\
2-.- \\
3 \ldots \\
4-\ldots \\
5 \ldots\end{array}$ & $\begin{array}{c}0.0159 \\
.0083 \\
.0144 \\
b .0184^{8} \\
.0137^{11}\end{array}$ & $\begin{array}{l}0.624 \\
.073 \\
.053 \\
.268^{3} \\
.317^{2}\end{array}$ & $\begin{array}{l}1.808 \\
(1) \\
.416^{3} \\
.487^{2} \\
.943\end{array}$ & $\begin{array}{r}2.317 \\
.230 \\
.311 \\
.651^{3} \\
1.368^{3}\end{array}$ & $\begin{array}{l}26 \ldots \\
27-\ldots \\
29 \\
30 \ldots \\
31 \ldots\end{array}$ & $\begin{array}{l}0.0117 \\
.0036^{11} \\
.025910 \\
.0065 \\
.0044\end{array}$ & $\begin{array}{c}0.092^{3} \\
.117 \\
.561^{2} \\
.066 \\
.025\end{array}$ & $\begin{array}{c}0.321 \\
.385^{1} \\
(1) \\
.284 \\
.422\end{array}$ & $\begin{array}{r}0.221 \\
.293 \\
1.924 \\
.410 \\
.296\end{array}$ \\
\hline $\begin{array}{r}6 \ldots . . \\
7 . \ldots \\
8 \ldots \\
9 \ldots \\
10 \ldots \\
\ldots\end{array}$ & $\begin{array}{l}.0081 \\
.0134^{8} \\
.0065^{14} \\
.0261 \\
.0171^{14}\end{array}$ & $\begin{array}{l}.026 \\
.033^{3} \\
.093^{3} \\
.192 \\
.210^{5}\end{array}$ & $\begin{array}{l}.154 \\
.352^{1} \\
.143^{3} \\
.549 \\
.536^{5}\end{array}$ & $\begin{array}{l}.121 \\
.604 \\
.4775 \\
.424 \\
.672\end{array}$ & $\begin{array}{l}32 . \\
33 . \\
35 . \\
36 . \\
37 .\end{array}$ & $\begin{array}{l}.0062^{11} \\
.0558 \\
.0046 \\
.0089^{11} \\
.0214^{11}\end{array}$ & $\begin{array}{l}.111 \\
.319^{3} \\
.0034 \\
.049 \\
.165\end{array}$ & $\begin{array}{l}.263^{3} \\
.288 \\
.041 \\
.414 \\
.430^{3}\end{array}$ & $\begin{array}{l}.240 \\
.592^{5} \\
.132 \\
.224 \\
.740\end{array}$ \\
\hline $\begin{array}{l}11 \\
13 \ldots \\
14 \\
15 \\
17\end{array}$ & $\begin{array}{l}.0132 \\
.0041 \\
.0038 \\
.0030 \\
.0350\end{array}$ & $\begin{array}{l}.071 \\
.079^{3} \\
.033 \\
.050 \\
.246\end{array}$ & $\begin{array}{l}.693^{2} \\
.356 \\
.565 \\
.328 \\
.738\end{array}$ & $\begin{array}{r}.346 \\
.766 \\
.258 \\
.425 \\
1.103\end{array}$ & $\begin{array}{l}38 \ldots \\
40 \ldots \\
41 \ldots \\
42 \ldots \\
43 \ldots\end{array}$ & $\begin{array}{l}.0054^{10} \\
.0196 \\
.0084^{\circ} \\
.0087^{10} \\
.14677\end{array}$ & $\begin{array}{l}.023 \\
.256 \\
.099 \\
.101^{3} \\
.017^{2}\end{array}$ & $\begin{array}{l}.218 \\
.493 \\
.597 \\
.782 \\
.032^{2}\end{array}$ & $\begin{array}{r}.202 \\
.671 \\
.244 \\
.654 \\
1.580^{1}\end{array}$ \\
\hline $\begin{array}{l}19 \\
20 \\
22\end{array}$ & $\begin{array}{l}.0234 \\
.0196 \\
.0142\end{array}$ & $\begin{array}{l}136 \\
.153 \\
.203\end{array}$ & $\begin{array}{l}.517 \\
.617 \\
.691\end{array}$ & $\begin{array}{l}.354 \\
.538 \\
.907\end{array}$ & & $\begin{array}{l}.0142 \\
.0291 \\
.0072 \\
.0105^{11} \\
\end{array}$ & $\begin{array}{l}.039 \\
.154 \\
.046 \\
.019^{3} \\
\end{array}$ & $\begin{array}{l}.286 \\
.135 \\
.140 \\
.093 \\
\end{array}$ & $\begin{array}{l}.353 \\
f \\
.693 \\
.443 \\
\end{array}$ \\
\hline $24 \ldots$ & $\begin{array}{l}.0061 \\
.0094\end{array}$ & $\begin{array}{l}.014 \\
.075\end{array}$ & $\begin{array}{l}.101 \\
.429\end{array}$ & $\begin{array}{l}.078 \\
.185\end{array}$ & $\begin{array}{l}\text { Average for } \\
\text { all soils }\end{array}$ & .0172 & .134 & .434 & .580 \\
\hline
\end{tabular}

a See table 1 for names of soils.

b. From most soils 12 cast caps and 4 nipples of each kind were removed. Superseript gives number when other than normal. 
Figure 8 shows that rate of loss of weight of the cast-brass caps was about half that for copper pipe in the same soils. This may have been the result of cathodic protection or because the cast alloys were more resistant to corrosion. The latter conclusion is suggested by the relative rates of corrosion of the castings, since those containing the least copper corroded the least.

The value for the Muntz metal nipples was about 50 percent higher than for pipes of the same material, while that for the galvanized

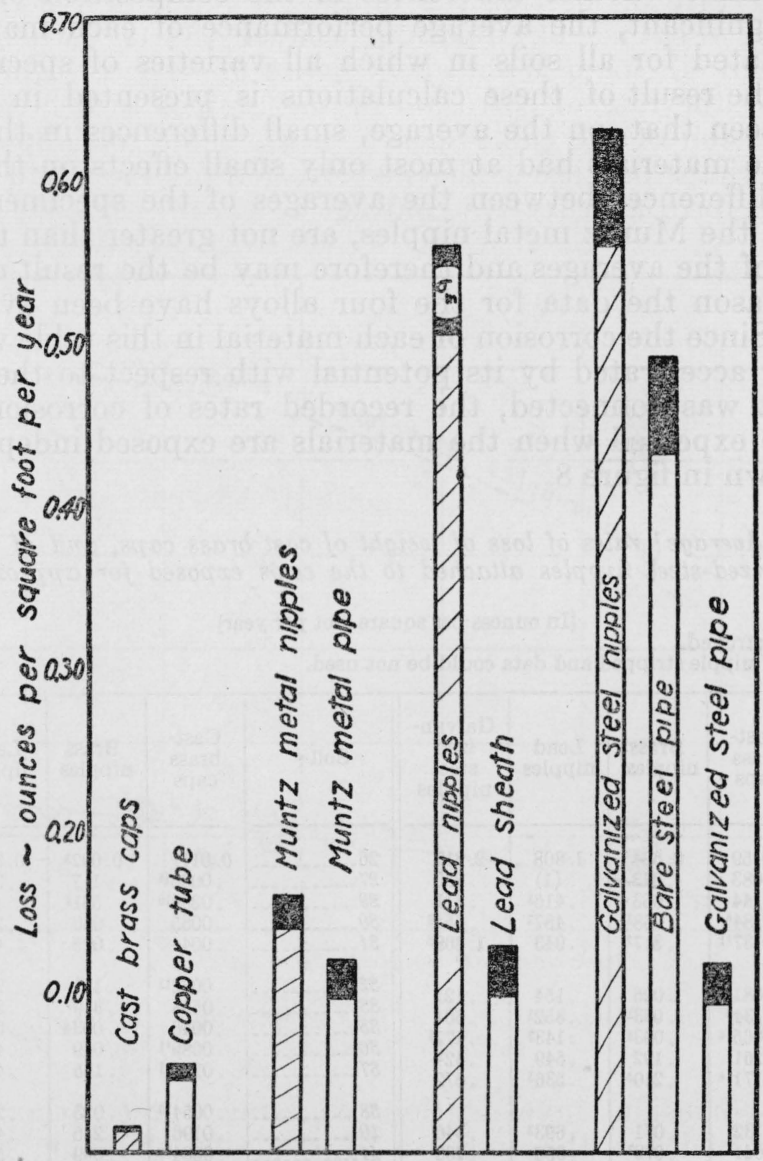

Figure 8.-Effect of interconnecting different metals.

The cross-hatched columns show the average rates of corrosion of the materials affected by galvanic action. The solid ends of the columns show the standard errors $\left(\sigma_{\mathrm{m}}\right)$ of the averages.

nipples was six times that for galvanized pipe in the same soils. The values for the galvanized nipples were about 25 percent greater than for unprotected steel pipe. Facts to be considered in this connection are that there was no zinc on about one-half inch of the nipples where they were threaded and probably the coating on the nipples was not as heavy as on the pipes.

A surprising result shown in figure 8 is that the lead nipples lost weight almost as rapidly as those of galvanized steel. Of course a partial explanation of this fact is that the density of the lead is nearly 
50 percent greater than that of the other metals. This explanation, however, scarcely seems adequate since in service lead connected to brass cocks has a reputation for lasting much longer than galvanized steel under similar conditions. It seems probable that if the nipples had been longer and larger with respect to the cast caps the results of the test would have been somewhat different.

The most striking difference was between the rates of loss of the lead nipples and the corresponding rates for the lead cable sheath. The average rate of loss for the nipples was about five times that for the cable sheath. The relation between the two when exposed to Hempstead silt loam is shown in figure 9. There seems to be a tendency for the rate of corrosion of the nipples to decrease. The rate of corrosion of the cable sheath in the same soil appears to be constant, perhaps because sufficient corrosion products had not been deposited to form an effective coating.

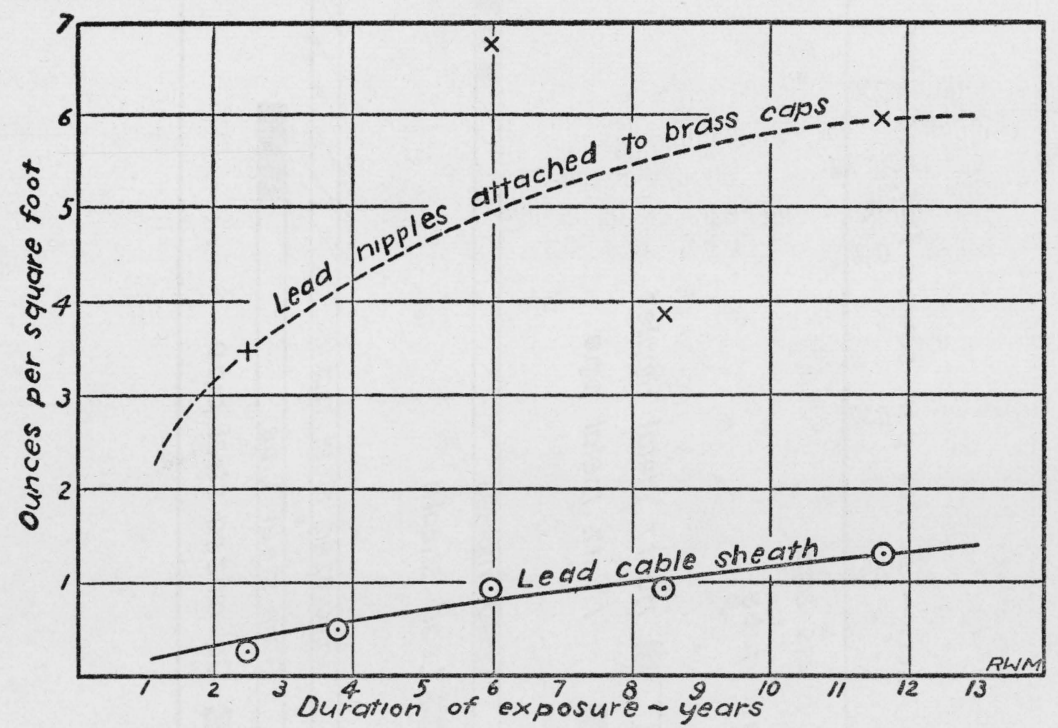

FIG. 9.-Comparison of losses of weight of lead nipples and cable sheath for different periods of exposure.

The soil-corrosion investigation contains three other sets of materials buried for the purpose of studying galvanic corrosion. The forms of these specimens are shown in figure 10. The unlabeled specimen consists of two strips of cast iron united by a brazed joint. The pipe from which the sections were cut was cast in a mold in which portland cement was used to prevent the metal from sticking: to the sand. The pipe manufacturer who prepared the specimens left the cement on them because this is the way the joint would be used in practice. For the same reason no care was taken to remove the flux used in making the joint. The uneven distribution of the corrosion may therefore be accounted for in several ways. However, after 8 years' exposure to a corrosive soil there was no serious corrosion at the joint.

Specimens of copper pipe joined by copper stream-line soldered fittings (M1, fig. 10) and specimens of a copper-silicon alloy pipe 


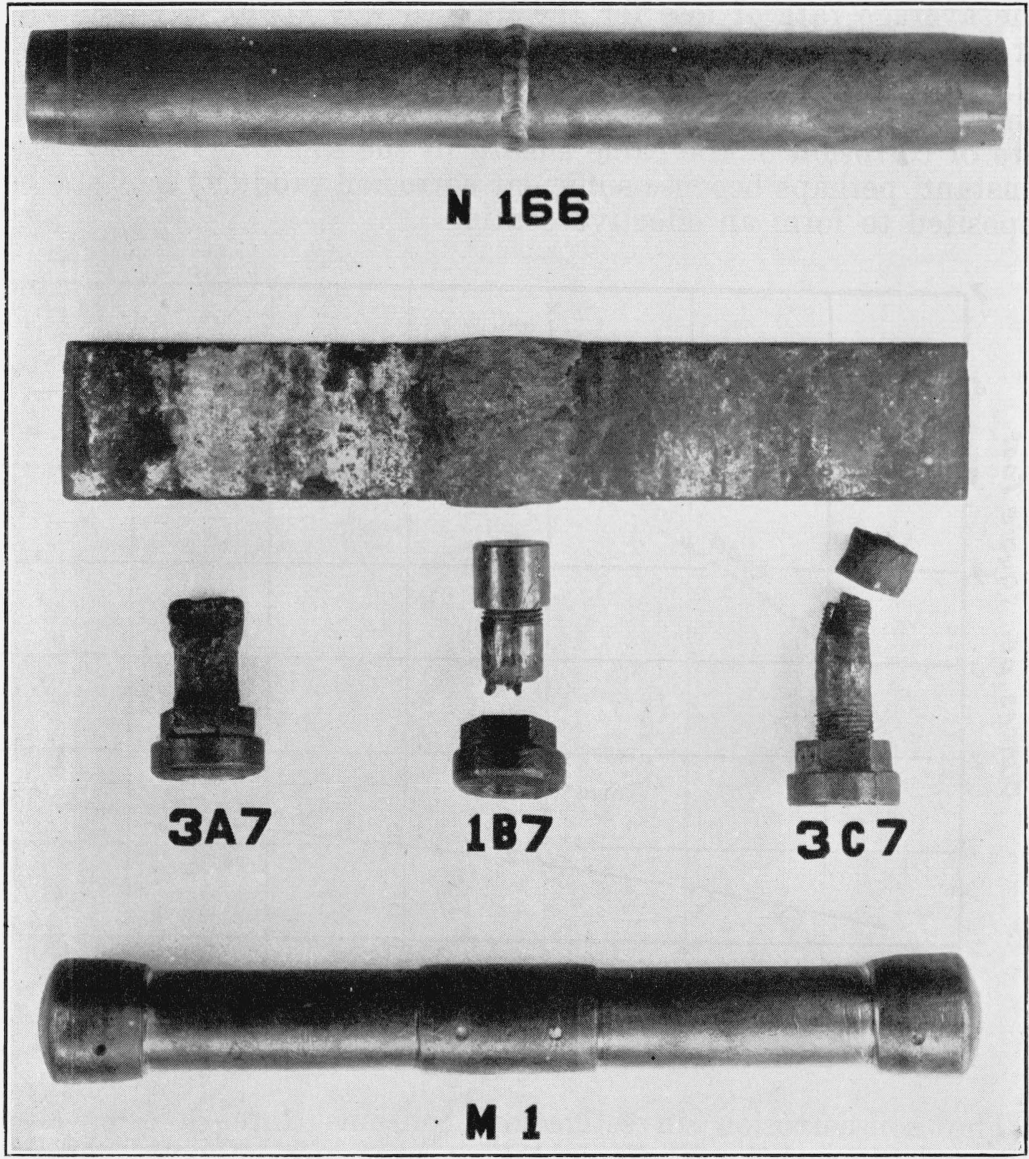

FIGURE 10.-Types of specimens used in studying the effect of joining dissimilar metals.

$N$, Copper-silicon alloy exposed to peat soil for 2 years; unnumbered, brazed joint on cast iron exposed 8 years; $3 A 7,1 B \gamma, 3 C \gamma$, cast brass caps attached to lead, Muntz metal, and galvanized steel, respectively, and exposed for 10 vears to Allis silt loam; $M 1$, soldered joints on copper pipe exposed 2 vears in a tidal marsh. 
with bronze welds at the middle of the specimens (N166, fig. 10) showed no definite evidence of corrosion which could be attributed to galvanic action after 2 years' exposure. The brass caps and attached nipples shown also in figure 10 are from a soil which is severely corrosive. They show the form of the specimens reported on in figures 8 and 9 , and in table 12 .

\section{DETERIORATION OF NONMETALLIC PIPE}

In addition to the large variety of specimens of metallic pipe and sheet, the soil-corrosion investigation includes two varieties of nonmetallic pipe developed for the transportation of water. These specimens buried while the materials were being developed do not represent the materials now marketed by those who furnished them. In both cases the manufacturers believe that their more recent products have overcome the weaknesses shown by the specimens.

The oldest nonmetallic specimens in the test were of wood fiber, coated inside and out with a bituminous substance which cracked and lost its plasticity in some soils. The fiber absorbed sufficient moisture to cause some of the specimens to increase in length about 5 percent. No tests of strength of the materials have been made. The coating had such a low melting point that it softened and became sticky when the specimens were exposed to the sun at the warmer test sites. The results of the test suggest that the pipe material itself should be more nearly moisture-proof since it has been demonstrated that moisture penetrates most thin bituminous coatings. It has also been shown that it is very difficult to secure and maintain a perfectly continuous bituminous coating on a pipe line because of the nature of bitumens.

The other material is composed of 85 percent of portland cement with the addition of 15 percent of asbestos fiber. The specimens of this material were exposed for approximately 2 years to 15 soils severely corrosive with respect to ferrous materials. As the specimens absorbed moisture, loss of weight determinations were not made. The specimens showed no pitting and it seemed best therefore to determine their condition by inspection.

The following comments were made by a representative of the manufacturer: "Inspection of specimens of asbestos cement pipe has shown surface corrosion on those samples which were in contact with acid soils and cinders. Also, some surface disintegration has been noted on those specimens in contact with soils containing soluble sulphates."

The test specimens were not representative of the grade sold as pressure pipe; therefore, the results may not be representative of what could be expected in the case of the more dense structure of pipe intended for pressure service. Until the specimens have been exposed for longer periods a detailed report on the condition of each specimen would add little to the above quotation.

\section{SUMMARY}

The data on the nonferrous specimens were insufficient to justify positive conclusions as to the rates of corrosion of the materials under any specific soil condition. However, the following conclusions are suggested by the data.

$99074-36-12$ 
1. No metal or alloy has been found superior to all others for all soil conditions, but for each condition some suitable material is available.

2 . With but few exceptions the rates of loss of weight and penetration were less for the nonferrous specimens than for the ferrous specimens subjected to the same soil conditions.

3. Lead in contact with some soils became badly pitted within a few years. Until the causes of this pitting are better understood, cable sheaths should be placed in direct contact only with soils known to be noncorrosive.

4. The differences in the rates of corrosion of different varieties of lead were small but the purest lead corroded the least. Antimonial lead appeared to corrode at a slightly higher rate than the commercial lead cable sheaths.

5 . The rate of corrosion of lead gradually decreased in some soils but appeared to be maintained in certain soils such as tidal marshes.

6 . The presence of chlorides, bicarbonates, and particularly sulfates, in soils favors the formation of films or deposits which retard corrosion of lead.

7. Copper and alloys high in copper corroded slowly in most soils. The highest rates of corrosion of copper occurred in soils containing sulfides.

8. The rates of corrosion of all copper alloys were higher in cinders than in any type of soil tested.

9 . The corrosion of copper and high-copper alloys was more nearly uniform over the surface than was the corrosion of ferrous materials in most soils.

10. Muntz metal dezincified in a considerable number of soils and probably should not be exposed to severe soil conditions.

11. The rates of corrosion of copper and brass appeared to change less with time than did the corresponding rates for ferrous materials.

12. Zinc corroded rather rapidly in a few soils. In some soils the loss of weight of zine was nearly proportional to the duration of the exposure. In such soils effective protective films were not formed. The protection which a zinc coating affords under such soil conditions is the result of cathodic protection at the expense of the zinc or due to the corrosion resistance of the zinc-iron alloy layers.

13. Aluminum and some of its alloys corroded rapidly under most of the soil conditions to which they were exposed.

14. The interconnection of dissimilar metals exposed to soil resulted in the partial protection of one of them and in more rapid corrosion of the other. Sometimes, however, the formation of corrosion products of one of the materials prevented continued corrosion.

The cleaning, weighing, and measuring of the specimens was done mostly by R. B. Hobbs, L. M. Martin, and I. Bohrer, on whose skill and care the reliability of the data largely depends. The last two made and checked most of the computations and assisted in the preparation of the tables and drawings. Dr. I. A. Denison and Mr. Martin made many valuable suggestions as to the interpretation of the data.

Washington, August 13, 1936. 